\title{
Home Bio-Waste Composting for the Circular Economy
}

\author{
Piotr Sulewski ${ }^{1}$, Karolina Kais ${ }^{2}{ }^{\circledR}$, Marlena Gołaś ${ }^{1}$, , Grzegorz Rawa ${ }^{1}$, Klaudia Urbańska ${ }^{1}$ and Adam Wąs ${ }^{1, *(D)}$ \\ 1 Institute of Economics and Finance, Warsaw University of Life Sciences-SGGW, Nowoursynowska 166, \\ 02-787 Warsaw, Poland; piotr_sulewski@sggw.edu.pl (P.S.); marlena_golas@sggw.edu.pl (M.G.); \\ grawa.sail@gmail.com (G.R.); klaudiaurbanska@onet.com.pl (K.U.) \\ 2 Institute of Environmental Engineering, Warsaw University of Life Sciences—SGGW, Nowoursynowska 166, \\ 02-787 Warsaw, Poland; karolina_kais@sggw.edu.pl \\ * Correspondence: adam_was@sggw.edu.pl; Tel.: +48-605-251-651
}

Citation: Sulewski, P.; Kais, K.;

Gołaś, M.; Rawa, G.; Urbańska, K.; Wąs, A. Home Bio-Waste Composting for the Circular Economy. Energies 2021, 14, 6164. https://doi.org/ 10.3390/en14196164

Academic Editors: Kacprzak Malgorzata and Gabriele Di Giacomo

Received: 31 July 2021

Accepted: 23 September 2021

Published: 27 September 2021

Publisher's Note: MDPI stays neutral with regard to jurisdictional claims in published maps and institutional affiliations.

Copyright: (c) 2021 by the authors. Licensee MDPI, Basel, Switzerland. This article is an open access article distributed under the terms and conditions of the Creative Commons Attribution (CC BY) license (https:// creativecommons.org/licenses/by/ $4.0 /)$.

\begin{abstract}
The consequence of the current economic development model is the generation of large amounts of waste and energy losses. One way to change this negative trend is a more rational use of raw materials reducing the amount of generated wastes. Biowaste, which may be divided into garden and kitchen waste, constitutes the main part of municipal waste. At the household level, it can be managed through composting - the most sustainable way of biowaste management. In this context, this paper aims to assess the economic and environmental effects of implementing the home composting incentive program introduced by one of the municipalities near Warsaw (Poland). The study is based on the estimation of the amount of biowaste generated in the commune, as well as on the number of households with the potential to compost biowastes. The effects of implementing the composting program were evaluated at different participation levels. The cartographic-based methods (GIS) were used in the analyses. Additionally, willingness to accept home composting by residents and its main determinants were examined. The results of the study indicate that the changes in the current household biodegradable waste management model are practicable and generate positive economic and environmental effects. However, the promotion of home composting requires active support from the local authorities, both in the financial dimension and by increasing residents' environmental awareness.
\end{abstract}

Keywords: biowaste management; circular economy; home composting; sustainable waste management

\section{Introduction}

The economic model dominating the modern world is based on a linear approach to production and consumption. Its consequence is the generation of large amounts of waste and energy losses [1-3]. The organization of economic processes according to this model causes environmental degradation and becomes one of the dimensions of the contemporary global ecological crisis [4-6]. According to World Bank [5], accelerating urbanization and the growing global population will result in an increase in the mass of waste generated in the next 30 years to 3.4 billion tonnes/year, compared to 2.01 billion in 2016 . In this context, increasing the degree of waste reuse (and thus reducing the consumption of natural resources and energy) is one of the key challenges in achieving the Sustainable Development Goals set by the United Nations [7-9]. In particular, the relationship between waste management and Goal 12 of "UN Sustainable Development Goals" [4] is emphasized, pointing to the need to "to ensure sustainable consumption and production patterns". The implementation of this goal in the EU countries is to be possible due to "A new Circular Economy Action Plan for a cleaner and more competitive Europe"-one of the blocks of the European Green Deal (Europe's new agenda for sustainable growth) [10]. Recycling at least $65 \%$ of municipal waste by 2030 has become one of the new EU waste policy targets [10]. Recycling of municipal waste is perceived today as one of the important elements of the transformation of the economy toward the circular economy model, which is an alternative 
to the linear approach [10-12]. Savini [3] underlines that "circular economy provides an approach to economic development that makes one problem the solution of the other in a sustainable way," which "is particularly evident in how biomass and biogas are now used to justify the value of organic waste as a long-term source of 'green' energy and bio-based raw materials". Among all municipal waste, biowaste is a category of waste that can be recycled at the household level through composting [13-15]. This is particularly important in the case of countries where treatment capacities (composting capacity and anaerobic digestion capacities) are lower than the collected biowaste. One of such countries is Poland, where, according to the European Environment Agency (EEA) estimations [14], an average of $100 \mathrm{~kg}$ of biowaste per person (collected separately and not separately) is collected (for comparison, according to Central Statistical Office (CSO) [16], the total waste generation per person in Poland is about $342 \mathrm{~kg}$ ), and in treatment capacities (installed treatment infrastructure including anaerobic digestion plant and composting plants), it reaches to $50 \mathrm{~kg}$ per person. Statistical data also show that $80 \%$ of these treatment capacities are based on anaerobic digestion treatment, while composting treatment accounts for only about $20 \%$ (on average, in the 21 analyzed countries, composting facilities currently account for $53 \%$ of biowaste treatment capacity, while anaerobic digestion accounts for $47 \%$ ) [14]. At the same time, less than $30 \%$ of biowaste is collected in Poland separately (the average for 32 EEA members and cooperating countries exceeds 50\%; in Germany, for example, $64 \%$ of municipal biowaste is collected separately). In Poland, over $85 \%$ of municipalities conduct selective collection of biodegradable waste. According to Central Statistical Office [16], about $1.61 \mathrm{mln}$ tons of biodegradable wastes in the country were collected separately in 2020 and $98 \%$ of this value $(1.58 \mathrm{mln} \mathrm{t})$ directed to composting or fermentation. For comparison, the total mass of municipal wastes amounts about $13.1 \mathrm{mln}$ tons, including $4,97 \mathrm{mln}$ tons of wastes collected separately (this means that only $37.9 \%$ of waste is collected separately) [16]. Estimations of EEA [14] indicated that separately collected biowaste in Poland constitutes about $30 \%$ of total amount of collected biowaste, which are rather poor results, as average for 32 EEA members and cooperating countries exceeds $50 \%$; in Germany, for example, $64 \%$ of municipal biowaste is collected separately. However, official statistics do not report what is the share of separately collected biodegradable waste in the total amount of biodegradable waste. This means that most biowaste is not reused in any way in Poland. At the same time, in many communes, the costs of maintaining a waste collection system exceed the revenues from contributions paid by residents for the maintenance of this system [17]. Therefore, it is reasonable to look for ways to increase the degree of biowaste processing in Poland, especially through home or local composting, which is indicated as the most sustainable way of biowaste management $[14,18,19]$. In this context, the main practical aim of this article was to assess the economic and environmental consequences of the implementation of a home composting incentive program entitled "Composter for Everyone" by one of the municipalities, which is currently struggling due to deficit of funds in the waste collection system. The program is being implemented in stages; hence, the full ex post assessment of its economic and environmental consequences will only be possible in a few years. The main research aim of the paper was evaluating overall economic and environmental effects of "Composter for Everyone" program (on the scale of the entire commune) before its completion, which is important from the point of view of promoting similar solutions in other cities/communes. Thus, our study contributes to ongoing discussions about appropriate/optimal system of municipal waste management. Taking into account the specified case, we hypothesize the following statements:

1. Subsidizing home composting using discounts in waste collecting fees and providing composters is profitable for the commune, as the reduction in waste management costs is greater than the loss of collected fees;

2. The current level of financial incentives is too low to encourage the majority of citizens to participate in the home composting program;

3. The majority of residents indicate a low level of perception of benefits from home composting, thus concentrating mainly on the economic aspects of home composting. 
The research is, therefore, a case study, as similar solutions have not been used intensively in Poland so far, and the initiative of the studied commune can be considered a pilot solution.

\section{Literature Review}

\subsection{Circular Economy}

The beginning of considerations on the circular economy (CE) is related to the essay by the American economist Kenneth E. Boulding, published in 1966, entitled "The Economics of the Coming Spaceship Earth", in which the author presented a vision of the economy as a circulation system of raw materials limited by environmental conditions, available resources, and possibilities of waste assimilation [20]. However, the concept of circular economy is not precisely defined, and its basic assumptions correspond, among others, with such concepts as "industrial ecology", "industrial symbiosis", "ecological economics", and "clean production" [21]. Nevertheless, currently, the concept of CE "represents a viable option for countries, governments, academia, and society to transform the linear and semi-circular materials and energy flows into circular flows and obtains better sustainable benefits" [22]. Furthermore, according to the Ellen MacArthur Foundation [2], a circular economy is a production system that aims to increase the use of renewable energy, eliminate the use of toxic chemicals that make it difficult to reuse and return to the biosphere of many products, and strives to eliminate waste owing to the excellent design of products, systems, and business models. Thus, the circular economy is expected to be the optimal way to sustainable development $[23,24]$.

The CE concept is based on principles [2] such as "design out waste" (waste does not exist when the biological and technical components (or nutrients) of a product are designed by intention to fit within a biological or technical materials cycle), "build resilience through diversity", "rely on energy from renewable sources", "think in 'systems' category", and "waste is food". The basis of the production processes in the circular economy is an approach to the product life cycle, referred to as "from cradle to cradle" (C2C), constituting an extension of the eco-efficiency approach dominant in the analysis "from cradle to grave", which covers all stages of the life cycle, from the extraction of materials to the end of life of the products [25]. The goal of the $\mathrm{C} 2 \mathrm{C}$ approach is to ensure (or improve) eco-efficiency at all stages of the product life cycle and to ensure that at the end of the product life cycle, the materials from which the product was made can be reused and recycled [26-29]. What is more, the implementation of the $\mathrm{C} 2 \mathrm{C}$ paradigm seeks to reduce the negative impacts, which is a distinguishing feature of other approaches in the organization of production systems based on eco-efficiency, as well as to stimulate and optimize positive impacts [27]. Thus, $\mathrm{CE}$ based on the $\mathrm{C} 2 \mathrm{C}$ paradigm strives to become a way of decoupling economic growth from resource extraction and natural environment degradation [2,21,30,31], although this assumption is not doubt-free [32]. The above literature review shows that the scientific debate on circular economy focuses mainly on the production sphere, although the assumptions of the $\mathrm{C} 2 \mathrm{C}$ concept cannot be implemented without significant consumer involvement [33-36]. This commitment is more and more often expressed in the postulate of sustainable consumption, which, according to the definition proposed at the Oslo Symposium $[37,38]$, assumes that "the use of services and related products, which respond to basic needs and bring a better quality of life while minimizing the use of natural resources and toxic materials as well as the emissions of waste and pollutants over the life cycle of the service or product so as not to jeopardize the needs of further generations".

The practical implementation of the assumptions of sustainable consumption (similar to sustainable production) can take various forms $[39,40]$, and one of them is changes in waste management [41,42] aimed at achieving a "zero waste" state [43-45]. Furthermore, in the context of sustainable development of cities and municipal waste management, the term "zero waste city" is also used [46]. 


\subsection{Composting as a Method of Waste Management}

Composting is one of the two basic and simplest (next to anaerobic digestion) treatment methods of separately collected biowaste [14]. Nowadays, more and more advanced solutions for biomass processing are also being sought, e.g., in various types of biorefineries [47]; however, composting, as probably the only method of waste treatment, can be applied in the household without the need for specialized equipment.

Composting is a safe aerobic process, during which, through the biodegradation of organic mass, a humic substance is formed, as well as by-products such as carbon dioxide, water, and thermal energy, etc., $[48,49]$. The composting process includes four basic phases: the mesophilic phase of hydrolysis and oxidation of organic matter, the thermophilic phase of decomposition of rapidly biodegradable organic substances, the phase of temperature drop and decomposition of other substances, and the phase of humus production [48,50]. It should be emphasized that the efficient course of the composting process requires good oxygen access; hence, it is crucial to prepare the organic material well and aerate the pile [48]. Composting is usually carried out in open-air windrows or in vessels, and the process works best with a good mixture of easily degradable wet organic materials such as food waste or garden waste [14]. The compost generated in the composting process can be used as fertilizer or soil improver, reducing the need for artificial fertilizers, which consumes energy and generates GHG emission [14,49]. It is indicated that composts have positive effects on the soil structure, contributing to the improvement of yield and reduction in erosion [51-53]. The advantages of composts also include [54-56] reduction in sanitary hazards related to waste treatment, elimination of unpleasant odors emitted by easily decomposing organic substances (especially in summer), reduction in mass and the volume of waste, reducing the area of landfills or obtaining your own organic fertilizer or soil for flowers. The disadvantages of composting include pathogen detection, low nutrient status, long duration of composting, long mineralization duration, and odor production [49]. Since the decomposition process is aerobic, composting generates greenhouse gases; however, some studies underline that composting as a method of waste treatment is much more sustainable, as compared to landfilling [57-60].

Home composting is a special category of composting (next to industrial composting) [61]. Home composting "can help recycle residential organic waste while reducing costs, energy consumption, and GHG emission during collection and transportation" [60,62-66]. Some doubts, however, are raised by the impact of home composting on GHG emissions during the process of microbial degradation of waste [13]. Although relatively little research has been conducted on the environmental impact of home composting, according to one study [13], home composting might generate GHG emissions due to microbial degradation of the waste and could generate other environmental contributions, e.g., leachate generation. However, the adopted technological solutions are significant for eliminating the occurrence of these disadvantages [60].

The degree of home composting popularization varies across the countries-the available data [61] indicate that, for instance, in the UK, about $40 \%$ of households with a garden reported being active home composters, and in Austria, about 1.5 million tonnes of biowaste were treated by means of home and neighborhood composting in 2009; about $5-10 \%$ of the households are home composting in the Netherlands, and about $14 \%$ in Sweden (in 2012). Currently, there are no data on the scale of home composting in Poland, although it should be noted that more and more municipalities responsible for waste management, following the example of solutions in other countries [61]), implement incentive systems to popularize this method of waste management.

\subsection{Municipal Waste Management in Poland}

The amount of municipal waste generated in Poland is, on average, $336 \mathrm{~kg} /$ per capita (for comparison, on average in the EU countries, this indicator in 2020 was $502 \mathrm{~kg} / \mathrm{capita}$ ) [67]. This means that nearly 12.8 million tons of municipal waste were generated annually in the country. According to the cited data, in the last 10 years, the level of municipal waste 
generation increased by slightly over $6 \%$. At the same time, the data of the EEA [14] show that, on average, about $1 / 3$ of generated municipal waste is biowaste, which means that about $110 \mathrm{~kg}$ of biowaste is generated per capita. This indicator in Poland has one of the lowest values among all European countries included in the EEA report (on average, it is almost $200 \mathrm{~kg}$ per person). It is also worth emphasizing that the average share of biowaste in municipal waste in European countries is slightly higher than in Poland (approximately $38 \%$ ) [14]. It should be borne in mind that the dissemination of the home composting model leads to a reduction in the share of biowaste in municipal waste requiring management [18]. According to EEA data [14], treatment capacities for biowaste in Poland are just over $50 \mathrm{~kg} /$ person. Zaleski and Chawla [68] cite data that indicate, however, that only about 848,000 tonnes of municipal waste are composted, which means only $\sim 22 \mathrm{~kg}$ per person. Other estimates [14] indicate that, on average, in 2016, only about $10 \mathrm{~kg}$ of biowaste compost was produced in Poland per person. Regardless of the existing discrepancies in the statistics, it can be stated that relatively little biowaste is produced per capita in Poland, but also little waste is managed in a sustainable way by composting or digesting.

Opportunities for the growing importance of composting as a method of biowaste management can be seen in the dynamically growing amount of municipal waste collected in Poland in a selective manner in recent years (Figure 1).

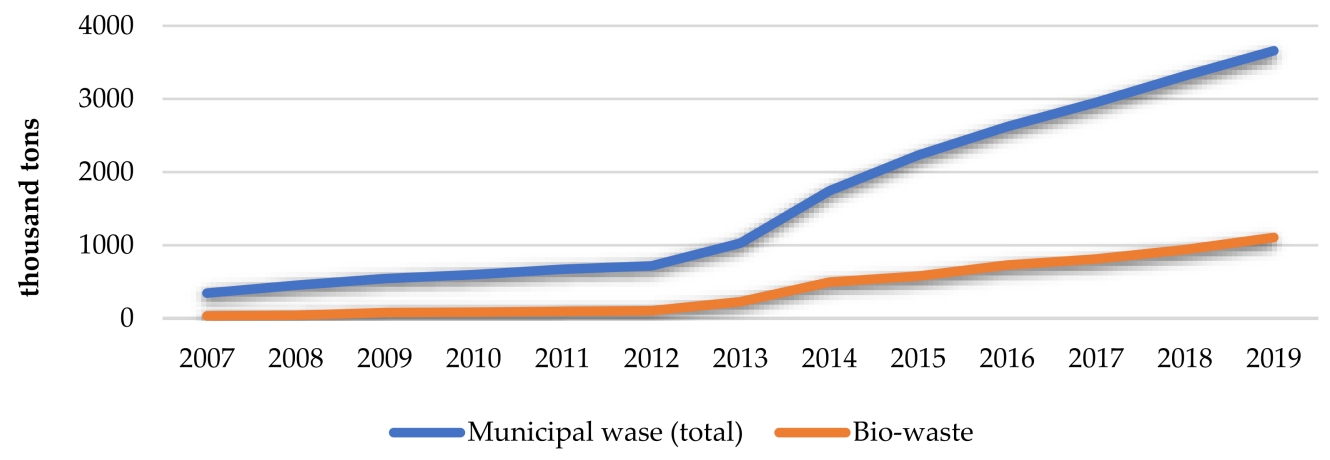

Figure 1. Biowaste collected in Poland separately. Source: CSO, waste collected separately during the year in Poland.

Among the factors driving this process, changes in legislation concerning the waste management system force the popularization of selective methods of waste collection. This is largely due to the implementation of the EU directive The Waste Framework Directive [69]. It regulates the goals and rules of waste management (shaping the waste management policy) in EU countries. The amendment to the directive adopted in 2018 provides the objective of increasing the reuse and recycling of municipal waste to a minimum of $65 \%$ in 2035 [70], while in 2018, the rate of municipal waste recycling was, on average, $47 \%$ in the EU, and in Poland, at the level of 34.3\% [71]; for comparison, in Austria, this indicator is over $80 \%$. Additionally, other EU documents aimed at the practical dissemination of circular economy are factors that lead to the acceleration of changes in the waste management system [10-12,35]. As a member of the EU, Poland is obliged to implement EU legal solutions into national law. Thus, increasing the recycling rate has become an important goal of the waste management policy. From 2014, Poland began to intensify efforts to popularize the circular economy, including in the field of municipal waste management [42]. Currently, the key guideline in this respect is the Roadmap "Transformation toward a Circular Economy" [72]. According to these assumptions, as well as the guidelines of the WFD directive, the basis of waste management should be the prevention of their generation, and then "reuse" and "recycle", which, in the case of bio-waste, includes composting and anaerobic digestion. One of the worst options in the field of municipal waste management is landfilling, which is the dominant method in Poland [68,73]. Both "composting" and "anaerobic digestion" require selective biowaste collection in order to obtain a good-quality base material that enables efficient microbiological processes [18]. Despite the increase in the amount of separately collected waste, 
including biowaste, a significant part of it (including biowaste) is collected non-selectively, which makes it difficult or impossible to use it as a raw material for compost production. The main barriers to selective waste collection in Poland are "lack of sufficient space for waste segregation at home, lack of appropriate containers in the area of residence, lack of willingness on the part of household members, lack of time, lack of faith that the waste will be re-used, insufficient information on waste sorting, or lack skills" [42]. Considering the existing barriers and challenges faced by Poland in terms of changes in the municipality of waste management, it is necessary to emphasize the justification of all citizens' actions to support the implementation of the CE in the country [42]. Home composting appears to be one of the simplest options for implementing this postulate; therefore, in this article, we attempted to assess the legitimacy of this action on the example of a typical suburban commune with a large number of single-family houses.

\subsection{Attitude toward Home Composting}

Ecological (environmental) awareness is considered to be one of the key factors influencing human behavior toward the natural environment [74]. Thus far, the issue of the attitudes of residents toward the possibility of composting waste and the environmental consequences of this process has not been the subject of in-depth scientific research in Poland. Various aspects related to waste segregation and the possibility of its recycling were analyzed $[75,76]$, although this issue was also not a frequent subject of research in the Polish literature on the subject. Nevertheless, for example, Korzeniowska-Ginter et al. [75] showed that the surveyed inhabitants of two Polish regions showed a positive attitude to the segregation of bakery and sugar waste, regardless of sociodemographic features. In some studies, however, attention was drawn to the residents' little care for the selective collection of biodegradable waste [77]. Other authors also observed that although many respondents showed an attitude in favor of segregating waste, they were not interested in building a comprehensive biowaste management system in their neighborhood [76]. Foreign literature on the subject provides examples [78], which shows that the propensity to compost depends on education, family, income situation, etc. Research by other authors shows that the attitude toward home composting may also depend on, e.g., professional status, income, and ownership of a flat [79]. Research in India has shown that Indian people who rent a flat more often segregate and compost waste and are also more interested in increasing environmental awareness. The results also suggest that those in the higher income group are more concerned about what happens to the waste in the further stages of its transport to the recipient. These individuals would be more inclined to implement segregation if they were convinced that the segregated waste would not be mixed later. Moreover, in the case of composting waste, people belonging to the lower income group would be willing to implement the process in exchange for receiving additional money from selling composts [79]. Similar conclusions were drawn from the research presented by Marcello et al. [80]. They showed that Tuscan citizens would be willing to implement waste composting in exchange for a small financial compensation [80]. Research by Bashir et al. [81] shows that few residents in the district of Kampar (Malaysia) compost food waste (approx. 4\%), and over 75\% of respondents do not segregate food waste at all. According to the authors, society would be more attentive to composting biodegradable waste if the composting practices were known to them. According to the authors, in order to encourage residents to compost food waste, it is necessary to conduct training for residents to raise environmental awareness in this area. Research by Tucker et al. [82] shows that the most important variables determining participation in home composting programs include having a favorable attitude toward what home composting involves, being knowledgeable about home composting, and the stage of the household in terms of the family life cycle.

\section{Case Study Area Description}

The commune of Łomianki, located in the immediate vicinity of the capital of Poland, Warsaw, (14 km from the center of Warsaw) (Figure 2), was selected to conduct this re- 
search [83]. The commune covers an area of $38.06 \mathrm{~km}^{2}$ and includes the town of Łomianki and nine smaller towns. The total housing stock in the commune of Łomianki is 10,335 properties (apartments in single-family houses and houses) [84]. On average, one property is inhabited by 2.6 people [84]. Proximity to a large city is a key feature of the commune from the point of view of municipal waste management, as it is dominated by single-family houses, and houses with gardens are the main source of biowaste. In 2019, the commune was inhabited by 25,465 residents registered for permanent residence [85]. Local authorities (Municipal Office), as in other towns, are obliged to organize a system of selective waste collection.

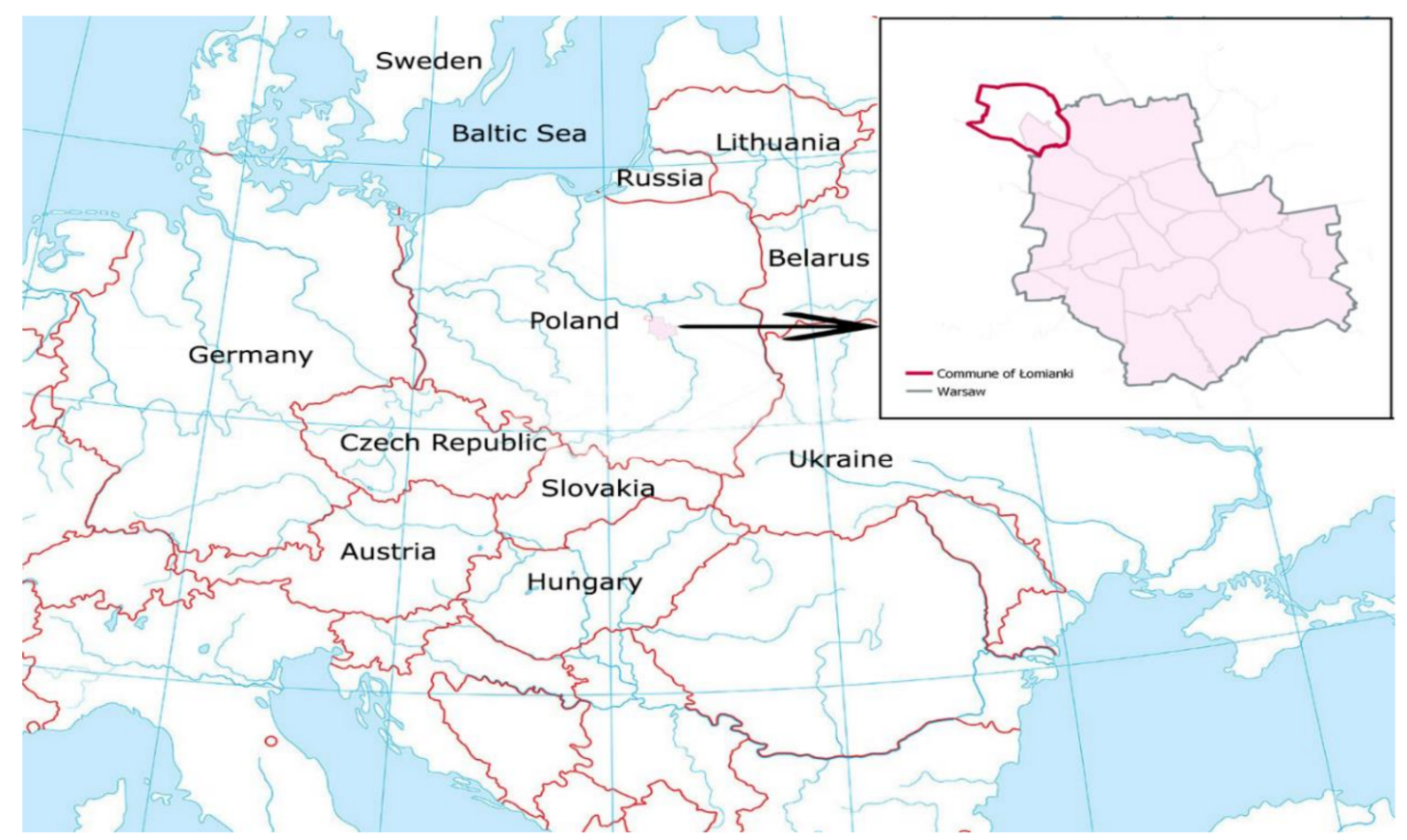

Figure 2. Localization of Łomianki Commune-the case study area.

The municipal authorities set the rates of fees for collecting waste from residents, from which they must finance the costs of the system's operation. The more waste the residents generate, the higher the costs of its management and the higher the residents' fees. According to official statistics, a total of 12,853.1 tons of municipal waste was collected in 2019. The total costs of waste management amounted to EUR 2.63 million. In an effort to reduce the costs of the system, the commune authorities proposed to the residents the "Composter for Everyone" program [86], the aim of which is to eliminate (reduce) the biowaste introduced into the communal management system. Although official data show that biodegradable waste accounts for only slightly more than $1 / 5$ of the total mass of waste collected in the commune, it is a significant component in mixed waste, which generates high costs (experts estimate that on average in Poland, up to $40 \%$ of mixed waste can be biowaste). Moreover, until the introduction of the municipal waste selective collection system, a systematic increase in biowaste entering the system was observed in the commune. In the program's assumptions, residents joining the program receive a composter for free (at the cost of the municipality) but, at the same time, undertake to cease supplying biowaste to the public system. It should be noted that the program was designed to act mainly by using economic incentives. Neither training nor any extension of services for inhabitants was provided in the first years of the program. There are also no precise data on the management of the self-produced composts, but on the basis of information from the local NGO [87] representative, it can be assumed that it is entirely used for fertilizing own gardens, as the commune is characterized by light sandy soils, which requires supplementing organic matter to provide proper growing conditions. 
The program is implemented in stages, and the effects of its functioning so far do not provide grounds for a full assessment of its legitimacy; hence, ax ante estimation analyses are needed.

\section{Materials and Methods}

In order to verify the hypotheses, the following research methods were used:

The number of households in the Łomianki commune having conditions for home composting was estimated, and the amount of biodegradable waste produced in them was estimated. The obtained results were compared with statistical data. The amount of waste for composting was estimated on the basis of the number of inhabitants and the area of home gardens estimated using GIS methods. The obtained results were compared with the amount of biowaste disposed of in the commune in the previous years.

Taking into account the amount and distribution of produced biodegradable waste, the number of composters needed for the full implementation of the home composting concept was determined.

The costs and benefits of implementing the home-composting program were determined at various levels of support in the form of lowering the fees for garbage collection and various levels of participation of residents. On this basis, the hypotheses concerning the economic efficiency of the system and the optimal level of reductions in waste disposal were verified. Additionally, the environmental benefits of limiting the transport of bio-waste to the point of disposal were estimated.

Bearing in mind the importance of the residents' "acceptance" of the idea of home composting, a questionnaire study was conducted to determine the residents' expectations regarding the idea of home composting and the main barriers to its implementation, which allowed for the verification of 3 hypotheses.

The analysis was based on the information contained in the document "Analysis of the State of Municipal Waste Management in the Łomianki Commune" in 2019 [88]. This report provides information on the amount of collected municipal waste divided into categories such as unsorted (mixed) waste, paper, and cardboard, plastic and metal, and glass (Table 1). Waste segregation into specified categories results from the regulations adopted at the national level $[89,90]$, which constitute the basis for the creation of cleanliness and order regulations by communes. In addition to the above categories of municipal waste collected directly from residents, the document also provides information on the amount of waste collected at a separate waste collection point.

Table 1. Categories and amount of waste collected in the commune of Łomianki.

\begin{tabular}{cc}
\hline Categories of Waste & Amount (tons) \\
\hline Unsorted (mixed) municipal waste & 5949.5 \\
Mixed packaging waste & 1529.46 \\
Glass packaging & 286.02 \\
Paper and cardboard packaging & 155.96 \\
Green waste & 2305.87 \\
\hline
\end{tabular}

Source: [88].

The presented data indicate the amount of biodegradable waste collected in a selective way, but they do not provide information on the content of biodegradable waste (mainly kitchen waste) that is in mixed waste. Therefore, the amount of kitchen waste included in the mixed waste category was estimated based on the number of residents and the unit production of kitchen waste per one person (based on the data from the literature [91]). The estimated amount of kitchen waste corresponded to nearly $50 \%$ of the total amount of mixed waste collected by the commune, which is close to the values estimated by other researchers dealing with municipal waste issues [92,93].

The verification of the hypothesis of the profitability of disseminating home composting (which is assumed to be connected with the necessity of equipping residents with composters and increasing the allowances for rubbish fees) in the study required a detailed 
economic analysis including the determination of potential costs and benefits. The starting point for this analysis was the assessment of the level of generated biowaste. The analysis of the composting potential included only people living in houses with lawns/gardens (7168 buildings with an average population of 2.6 people). It was assumed that for organizational reasons, composting waste in households without a garden is difficult to implement and would not be considered in the study. The number of houses and biologically active surface area were determined using data from the Web Map Service (WMS), which considers services provided by the Main Office of Geodesy and Cartography, as well as data previously collected in the National Geodetic and Cartographic Resource. The calculations were made using the QGIS 3.14 program based on the following services: standard orthophoto map, state register of borders, territorial units, and national integration of land records. It was assumed that there are 7168 properties (households) with gardens in the commune. A sample of 600 representative polygons, distributed evenly across its area (properties may include several surveying plots), were selected from this population of single-family houses. The property boundaries were read from the standard orthophoto map, and then their boundaries were designated by adding a vector layer on the National Integration of Land Records. On this basis, it was calculated that the average biologically active area per household is $765.24 \mathrm{~m}^{2}$. Dividing the total mass of green waste collected in the commune by the area, the average green mass yield per $1 \mathrm{~m}^{2}$ of the biologically active area was assumed. A summary of the adopted assumptions regarding the unit production of biodegradable waste (kitchen and green waste) is presented in Table 2.

Table 2. Assumptions made regarding the unit production of biodegradable waste, taking into account the differentiation during the year.

\begin{tabular}{ccccc}
\hline \multirow{2}{*}{ Months } & \multicolumn{2}{c}{ Kitchen Waste } & \multicolumn{2}{c}{ Green Waste } \\
\cline { 2 - 5 } & kg per Person & $\mathbf{d m}^{\mathbf{3}}$ /Person & kg per sq.m $\mathbf{~}^{\mathbf{1}}$ & $\mathbf{d m}^{\mathbf{3}}$ /sq.m \\
\hline January & 8.9 & 12,7 & 0.00 & 0.00 \\
February & 6.8 & 9.7 & 0.00 & 0.00 \\
March & 11.2 & 16.0 & 0.00 & 0.00 \\
April & 11.5 & 16.5 & 0.00 & 0.00 \\
May & 12.0 & 17.1 & 0.10 & 1.74 \\
June & 13.5 & 19.3 & 0.11 & 1.96 \\
July & 14.6 & 20.8 & 0.07 & 1.31 \\
August & 17.5 & 25.0 & 0.07 & 1.31 \\
September & 19.5 & 27.9 & 0.06 & 1.09 \\
October & 13.1 & 18.7 & 0.04 & 0.65 \\
November & 11.5 & 16.5 & 0.00 & 0.00 \\
December & 13.5 & 19.3 & 0.00 & 0.00 \\
Total & $\mathbf{1 5 3 . 6}$ & $\mathbf{2 1 9 . 4}$ & $\mathbf{0 . 4 6 0}$ & $\mathbf{8 . 1}$ \\
\hline
\end{tabular}

${ }^{1}$ Assuming that the bulk density of kitchen waste is $0.7 \mathrm{~kg} / \mathrm{dm}^{3}$ and that of green waste is $0.3 \mathrm{~kg} / \mathrm{dm}{ }^{3}$. Source: own study based on [91,94].

The parameters for the unit biowaste production, as well as the area and diversity of plots determined in the above procedure, were used to determine the demand for composters. When estimating the necessary capacity of the composter, it was assumed that the volume of the batch decreases in the first month by $30 \%$ of the original volume, in the second by another $15 \%$, and in the third by another $5 \%$ [95,96]. It was assumed that the first partial emptying of the composter would occur nine months after the first loading (assuming that the composting process would start at the beginning of the year, it would enable the first part of compost to be used for autumn garden treatments) and would cover $1 / 3$ of the collected load (the literature of the subject indicates that depending on the intensity of aeration, the degree of fragmentation, temperature, humidity, and the $\mathrm{C} / \mathrm{N}$ ratio, the composting process may take from 3 months to even more than a year [64,97-99]). According to specialists [100], continuing or even starting composting during the winter is possible; thus, we assumed that process is ongoing year-round (the process stops only 
when the materials are completely frozen; however, in large bins, organic matter will probably stay warm enough to avoid freezing, and the bin can also serve as cover). In the analyses, a composter with a capacity of $900 \mathrm{dm}^{3}$ was adopted as the base unit (which resulted from the solution practiced in the studied commune as part of the pilot project "Composter for Everyone"). Schematically, the conceptual model used to determine the necessary number of composters is shown in Figure 3, while Figure 4 shows the level of filling in the composter in accordance with the adopted assumptions.

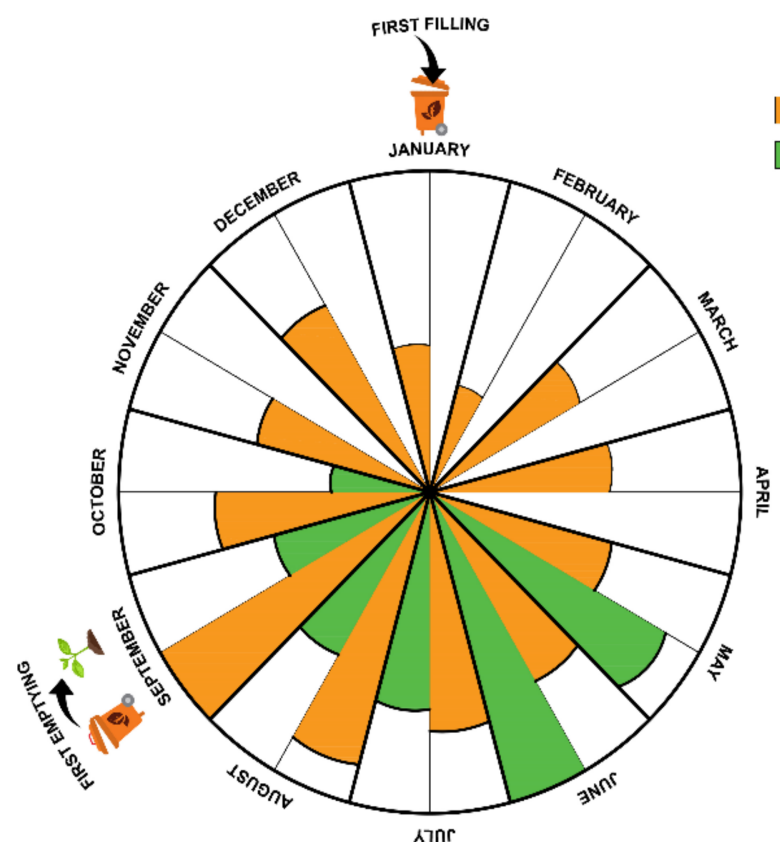

FIRST YEAR
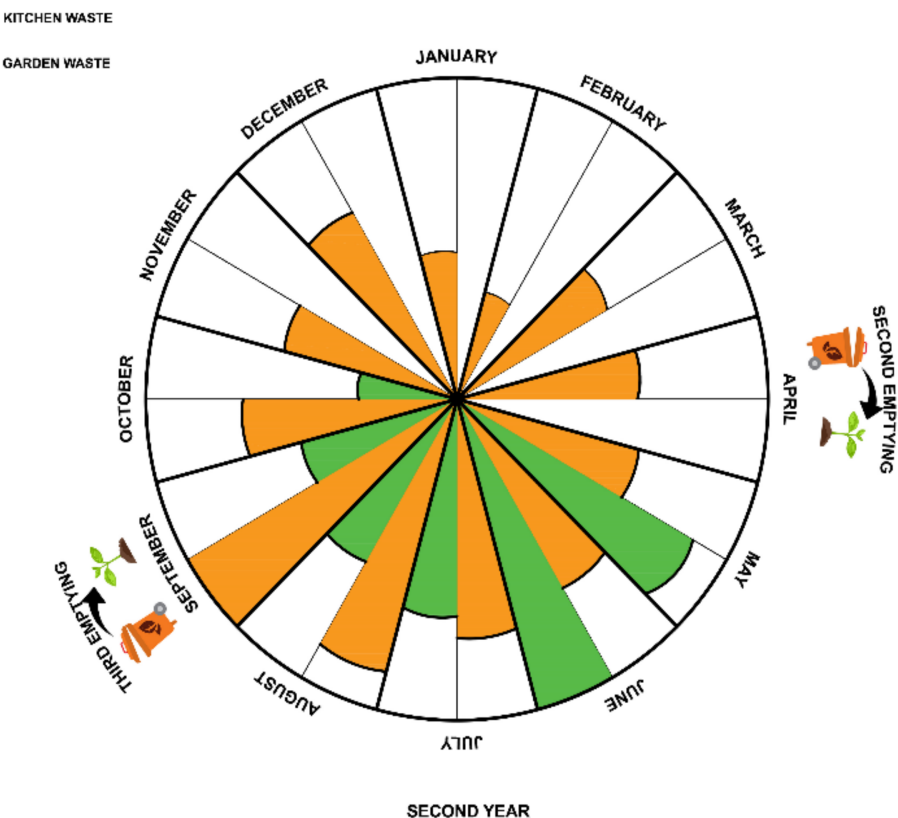

Figure 3. Schematic process of filling and emptying the composter with kitchen and garden (green) waste.

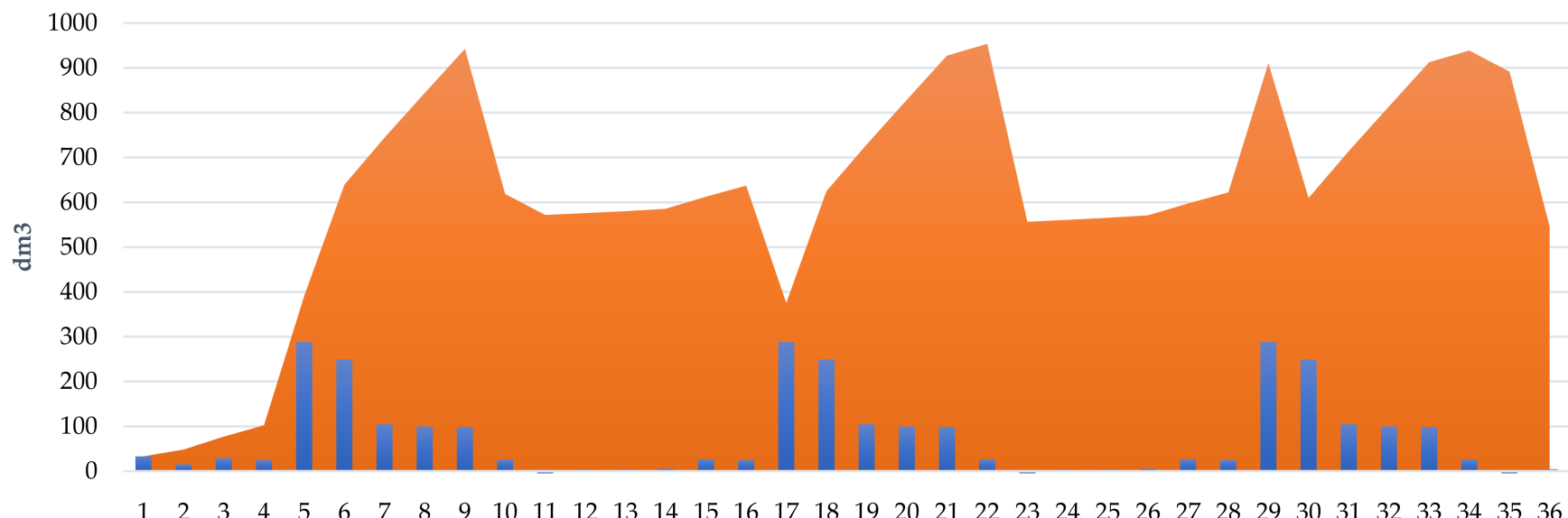

Figure 4. Changes in filling the composter.

In the case presented by us, the quality of home-composting composts was tested. The literature on the subject, however, indicates that self-composting allows for obtaining composts with good parameters (which does not mean that all residents succeed in it). Analyses by Vázquez and Soto [66] on 90 composting bins indicate that operation of composting bins by users was successful, as indicated by a low $\mathrm{C} / \mathrm{N}$ ratio (10-15), a low number of inappropriate materials (or physically contaminant materials, mean of $0.27 \pm 0.44 \%$ dry matter), low heavy metal content ( $94 \%$ of samples met required standards 
for agricultural use) and high nutrient content $(2.1 \% \mathrm{~N}, 0.6 \% \mathrm{P}, 2.5 \% \mathrm{~K}, 0.7 \% \mathrm{Mg}$ and $3.7 \% \mathrm{Ca}$ on average, dry matter). To the best of our knowledge, no similar studies have been published in Poland thus far. The literature on the subject on the practical aspects of home composting in Polish conditions shows that mature compost is obtained after 6-12 months [101]. At the same time, it should be borne in mind that composts remaining for too long mineralize and lose humus, hence the adopted scheme for emptying the composter.

The estimation made on this basis shows that the total needs of the commune are 9605 composters, while (with the assumed filling and emptying scheme) $61.6 \%$ of households need one composter, $33.5 \%$ need two composters, and $1.7 \%$ of households need three or more composters. From further analysis, 3.3\% of households with the smallest garden area were eliminated, as the amount of biowaste produced was too small. Ultimately, the number of households potentially eligible for the program was 6928 units.

The number of composters estimated on the scale of the commune (taking into account the needs of households) that were necessary to manage the produced biodegradable waste was the basis for determining the economic profitability of the project consisting of equipping the inhabitants with composters by the commune. According to the data obtained from the Commune Office, the cost of purchasing one composter in the pilot phase of the program was at PLN 500 (EUR 110) (with a volume of $900 \mathrm{dm}^{3}$ ). The assessment was carried out using the simple payback period and internal rate of return (IRR) and updated cash flow (NPV) analysis assuming the planned useful life of the composter of 10 years. The interest rate on 10-year treasury bonds was adopted as the interest rate for the comparisons (1\% per annum plus inflation; assuming inflation at the average level for the last 10 years). In this analysis, the category of investment expenditure was the commune's expenditure on the purchase of compost bins, while the income category was the commune's savings in terms of waste management costs reduced by lost contributions from residents (management of $1 \mathrm{t}$ of biodegradable waste costs PLN 658.9; EUR 145) -in exchange for switching to home composting, residents receive a discount as part of the waste management fee in the amount of PLN 2 per month ( 0.45 EUR/month). Therefore, the value of net present cash flows can be expressed in the following general formula:

$$
N P V=\sum_{i=0}^{n} \frac{(S-P)_{t}}{(1+i)^{t}}-1
$$

where

$N P V$ - net present value;

$(S-P)_{t}$ - cash flows in subsequent years calculated as savings in the costs of the waste management system $(S)$ minus discounts in fees collected from residents;

$I$-initial investment inputs related to the purchase of composters;

$i$-alternative investment interest rate;

$t=0,1,2, \ldots, 10$-subsequent years of the calculation period.

One of the factors determining the level of biowaste management costs is the transport of biowaste to a composting plant located about $41.8 \mathrm{~km}$ away from the studied commune, which is also a source of GHG emissions. The assessment of the potential GHG reduction was carried out assuming that the transport of 1 ton of waste generates emissions at the level of $184.5 \mathrm{~g} \mathrm{CO}^{2} / \mathrm{tkm}$ (tonne-kilometer) [102].

The economic analysis was supplemented with a survey of residents' attitudes, the main purpose of which was to identify their tendency to implement composting and resign from donating biowaste to the municipal waste collection system. The research was carried out using the diagnostic survey method on a sample of 100 volunteers living in the houses in the Łomianki commune. The survey was performed in April and May of 2020 using an online form. The survey consisted of 16 questions that were set up to find out whether the respondents use a home composter, what their opinions are regarding the pros and cons of the idea of biowaste composting, what barriers hamper home composting 
of biowaste, expected level of deduction in waste collecting fee for home composting of biowaste, preferences regarding actions toward nature conservation, and also basic data regarding their education and economic status.

The descriptive statistics of the survey's results provided arguments for verifying the hypothesis assuming insufficient financial incentive for inhabitants of the town and the hypothesis about the low perception of home-composting benefits among the dwellers.

\section{Results}

Based on official statistical data [88] and the assumptions mentioned above, it was found that a total of $5388.3 \mathrm{t}$ of biowaste is generated in the commune, of which $46.9 \%$ is green waste collected from gardens, the formation of which is characterized by high unevenness related to seasonal changes. The total mass of waste collected by the commune is $12,853.1 \mathrm{t}$, which means that biodegradable waste constitutes about $42 \%$ of the total waste collected in the communal management system. The distribution of biowaste generated in the commune is shown in Figure 5. A high level of the unevenness of generated waste throughout the year is one of the parameters that should be taken into account when determining the minimum needs for the provision of composters for residents.

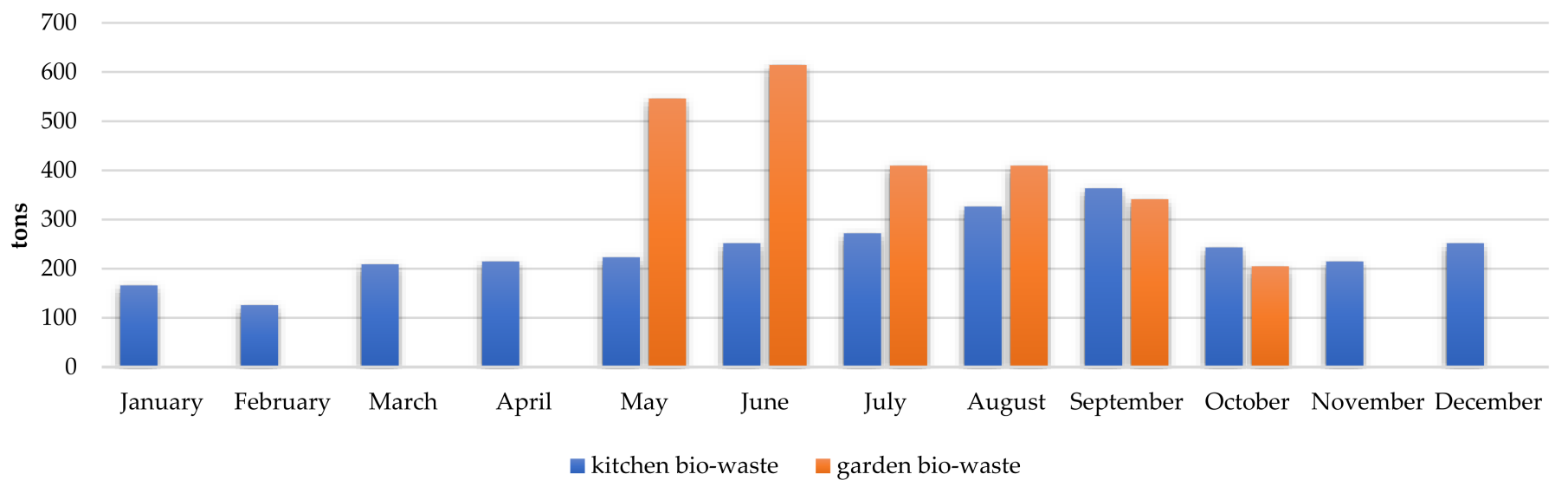

Figure 5. The amount of biowaste generated in the studied commune, broken down into green and kitchen waste. Source: own study base on Municipal Office data.

The management of the abovementioned amount of biowaste in a traditional management system (collection from residents and transport to an external enterprise) is associated with costs and GHG emissions. The distribution of the emission in the year is presented in Figure 6. The total estimated annual costs of biowaste management were PLN 3.55 million (EUR $~ 0.789 \mathrm{mln}$ ), while the total costs of collecting all waste amounted to PLN 11.1 million (EUR 2.44 mln) (excluding administrative costs) [88], which means that the share of biowaste in the total costs of the system was at the level of about $32 \%$-therefore, it was proportionally lower than it would appear from the relation of the mass of the collected waste. Emissions associated with the transport of collected waste to a composting plant located more than $40 \mathrm{~km}$ from the studied commune amounted to a total of 41.5 thousand $\mathrm{kg}$ of $\mathrm{CO}_{2} \mathrm{e}$. 


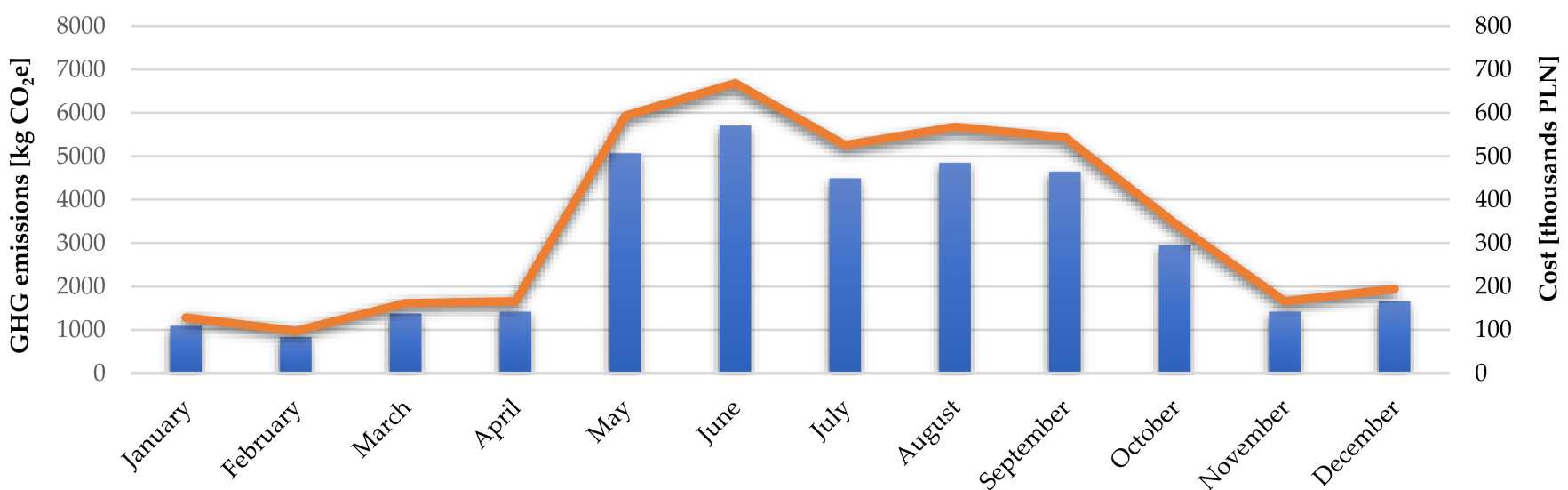

Cost of prosessing bio-waste for the Łomianki Commune [right axis] $\longrightarrow$ GHG emission due to bio-waste transportation [left axis]

Figure 6. Monthly costs of managing biowaste and the level of GHG emissions related to its transport to the composting plant.

Despite the fact that the costs of biowaste management turned out to be slightly lower than the average of the other groups, it should be emphasized only this group can be disposed of by the residents on their own. This would allow the elimination of both the abovementioned $\mathrm{CO}_{2}$ emissions resulting from transport and the costs related to the utilization of biowaste by an external composting company. The total elimination of the costs of collection and processing of biowaste would correspond approximately to $75 \%$ of the deficit in the budget of the waste management system (the collected fees for residents in 2019 were over 4.6 million PLN (EUR $1.02 \mathrm{mln}$ ) lower than the costs of maintaining the system, which should be self-financing). It should be borne in mind that the transition to the home-composting system would, at the same time, reduce the revenues from contributions for the maintenance of the biowaste collection system. Currently, households that resign from introducing biowaste to the waste collection system can take advantage of a discount of PLN 2 (EUR 0.44) per person (6\% of the premium due), which, given the average number of inhabitants per household, means a benefit of PLN 5.2 (EUR 1.22)/month/household. The survey shows that most of the respondents would be willing to switch to home composting at a much higher level of deduction (Figure 7). Only about $12 \%$ of respondents would expect a fee reduction of no more than $15 \%, 46 \%$ of respondents would expect a reduction in the range of $16-30 \%$, and $36 \%$ would agree to switch to home composting in exchange for a reduction in the range of $31-50 \%$.

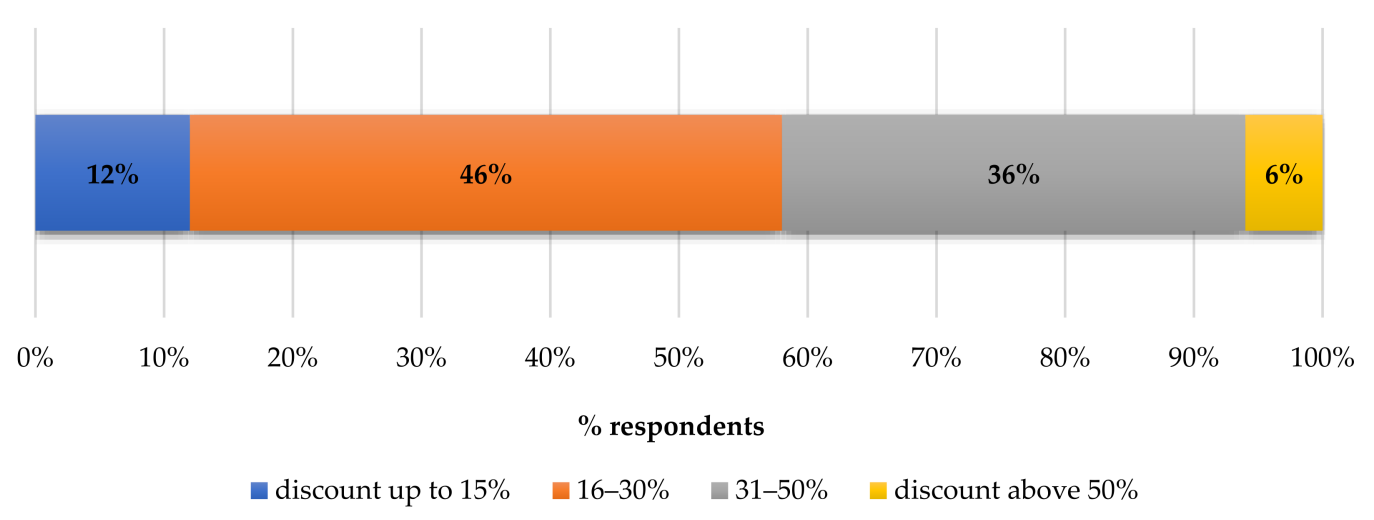

Figure 7. The amount of biowaste generated in the studied commune, divided into green and kitchen waste. Source: own study base on the survey. 
Taking into account the above expectations, an assessment of the economic efficiency of the investment consisting in equipping the inhabitants of the studied commune with home composters (900 L capacity) was carried out at four levels of deduction in their contribution to the waste collection system, i.e., $15 \%, 30 \%, 50 \%$, and $75 \%$ of the base fee level. Table 3 presents detailed data used in the profitability account, while Table 4 presents the results of the investment efficiency analysis.

Table 3. Parameters and assumptions used in the profitability account of investments in home composting (equipping residents with composters).

\begin{tabular}{|c|c|c|c|c|c|}
\hline & \multicolumn{5}{|c|}{$\begin{array}{c}\text { Discount in the Residents' Contribution to the Waste Management } \\
\text { System }\end{array}$} \\
\hline & $\begin{array}{c}6 \% \\
\text { (Current) }\end{array}$ & $15 \%$ & $30 \%$ & $50 \%$ & $75 \%$ \\
\hline Standard annual premium (fee) PLN/person & 396 & 396 & 396 & 396 & 396 \\
\hline Reduced premium (fee) PLN/person & 372 & 336.6 & 277.2 & 198 & 99 \\
\hline Number of people included $(2.6 \times 6929$ households $)$ & $18,015.6$ & $18,015.6$ & $18,015.6$ & $18,015.6$ & $18,015.6$ \\
\hline Due contribution (fee) $100 \%$ at the commune level [thousands PLN] & 7134.2 & 7134.2 & 7134.2 & 7134.2 & 7134.2 \\
\hline $\begin{array}{c}\text { Deduction at the commune level—lost revenues (commune cost) } \\
\text { [thousands PLN] }\end{array}$ & 432.4 & 1070.1 & 2140.3 & 3567.1 & 5350.6 \\
\hline $\begin{array}{l}\text { Estimated reduction in system costs at the commune level (fees } \\
\text { paid by the commune for biowaste treatment) [thousands PLN] }\end{array}$ & 3363.3 & 3363.3 & 3363.3 & 3363.3 & 3363.3 \\
\hline $\begin{array}{l}\text { One-off expenditure of the commune for the purchase of } \\
\text { composters (PLN } 500 \times 6929 \text { households) [thousands PLN] }\end{array}$ & 4802.6 & 4802.6 & 4802.6 & 4802.6 & 4802.6 \\
\hline
\end{tabular}

Source: own study base on Municipal Office and statistical data.

Table 4. The results of the investment profitability account for five variants of the level of deduction in the contribution paid by residents.

\begin{tabular}{cccccc}
\hline & \multicolumn{5}{c}{ Discount in the Residents' Contribution to the Waste } \\
Management System
\end{tabular}

The accession to the program of all eligible households would mean a one-off expenditure on the purchase of composters at the level of PLN $4.8 \mathrm{mln}$ (EUR $1.06 \mathrm{mln}$ ). At the same time, it would mean a decrease in revenues of PLN 432.4 thousand (EUR 96 thousand) to the commune budget annually due to waste fee deduction at the current level $(6 \%)$ to over PLN $5.35 \mathrm{mln}$ (EUR $1.18 \mathrm{mln}$ ) in the event of a $75 \%$ waste fee reduction.

On the other hand, such action would allow the elimination of biowaste from nearly 7 thousand households, which would entail the elimination of over 5.1 thousand tons per year of biowaste from the collection system (assuming that all kitchen and green waste from these households would be composted). With the cost of utilization of $1 \mathrm{t}$ of biowaste at the level of PLN 658.7( 146 EUR)/t incurred currently by the commune, this would mean savings at PLN $3.36 \mathrm{mln}$ (EUR 747 thousand). The analysis shows that with the adopted variants, the investment consisting in equipping households with gardens with composters would be profitable in three of the considered variants, i.e., with a premium reduction of $6 \%, 15 \%$, and $30 \%$. The additional simulation showed that the maximum deduction level ensuring NPV $=0$ is $39.13 \%$. A higher level of fee deduction for the waste collection system that some residents would expect would entail negative net cash flows. In the case of a $6 \%$ discount (real option), the purchase of composters would be returned in less than two years, and the internal IRR rate would be over $60 \%$.

However, as shown by the survey results, such a level of the deduction of a fee would be acceptable to a small part of the inhabitants. Therefore, achieving a high degree of participation with such a level of deduction would be unlikely. Taking into account that 
the largest group of people is ready to join the program with fee deduction in the range of $15-30 \%$, it can be assumed that a solution based on applying for a deduction at the level of about $30 \%$ would be satisfactory for the majority of residents. At the same time, it can be indicated that the "fair" premium reflecting the share of biowaste management costs in the total costs of the system is $28.6 \%$ (PLN 3,550,000/PLN 12,392,000). With the introduction of the $30 \%$ fee deduction, the investment consisting in equipping eligible households with composters would pay off within four years (simple payback period), and the internal rate of return would be almost 22\% (NPV PLN 5,292,000; EUR $1.18 \mathrm{mln}$ ).

An important problem in the presented situation is that over $42 \%$ of the surveyed residents would expect a premium reduction of over 30\% (including a $6 \%$ reduction of over $50 \%$ of the current premium). Taking into account the results of the investment profitability analysis and the estimated "fair premium", it should be stated that such expectations are too high. On the other hand, it is worth noting that over $18 \%$ of the surveyed residents declared no interest in implementing home composting, regardless of the potential reduction in the contribution to the waste management system. At the same time, almost $1 / 3$ of the respondents declared participation in the composting program without binding such a decision to a deduction in fee (Table 5).

Table 5. The results of the investment profitability account for five variants of the level of deduction in the fee paid by residents.

\begin{tabular}{|c|c|c|c|}
\hline & Definitely YES & $\begin{array}{l}\text { YES, but Expects a Larger } \\
\text { Discount on the Waste } \\
\text { Collection Fee }\end{array}$ & NOT Interested at All \\
\hline $\begin{array}{l}\text { Share of respondents declaring their } \\
\text { willingness to join or continue } \\
\text { participation in home composting }\end{array}$ & $32.4 \%$ & $49.0 \%$ & $18.6 \%$ \\
\hline
\end{tabular}

Source: own study base on the survey.

Among the reasons for the reluctance to join the home-composting program, the most frequently indicated was the lack of space for a composter, the lack of time to deal with composting, a general reluctance to compost, not perceiving the need for composting, and the lack of skills (Figure 8).

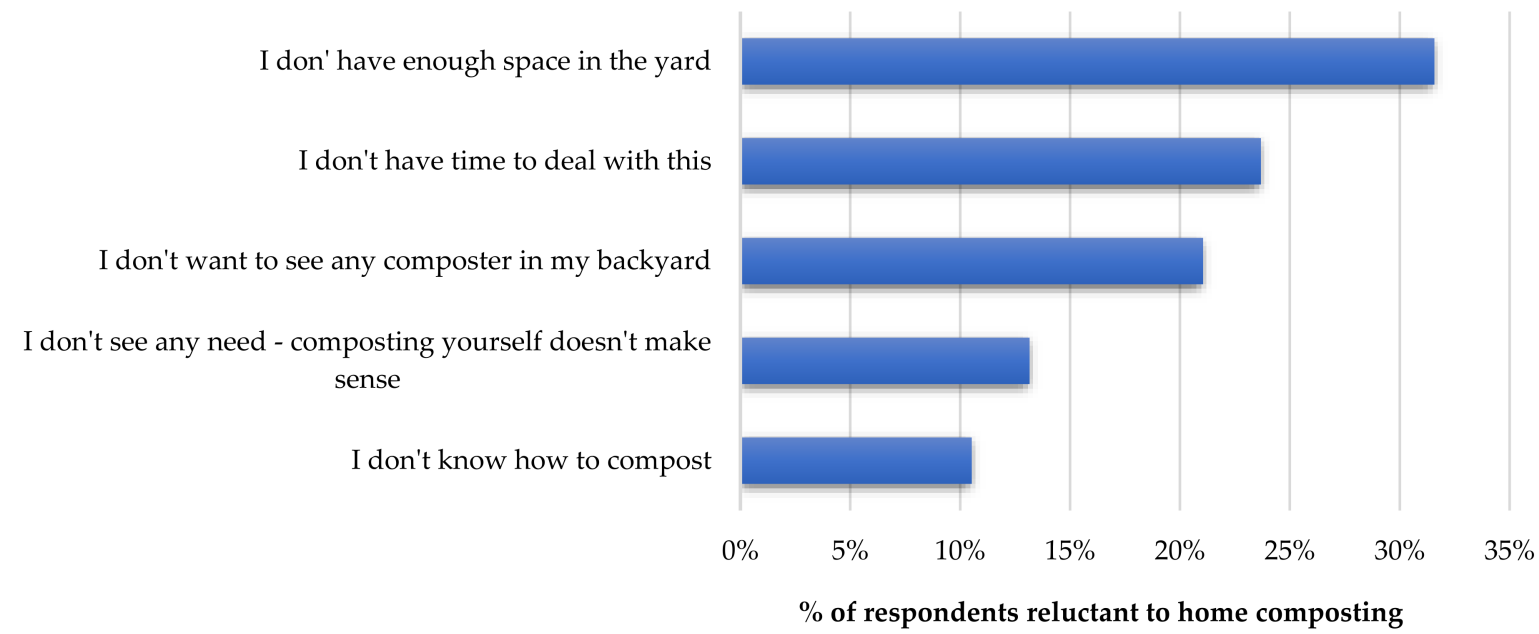

Figure 8. Declared reasons for reluctance to home composting among the inhabitants of the studied commune. Source: own study base on the survey. 
The results of the study in the category of reluctance to home composting suggest the need to disseminate knowledge, both about the technology of composting and the benefits of using it. The surveyed respondents highlighted the fact that a particularly important feature of home composting is "producing something useful from waste" (Figure 9). The composting process was perceived as slightly less beneficial regarding "the ability to independently produce valuable fertilizer" and "reducing the consumption of plastic bags that are used to collect biowaste". Even lower benefits were perceived due to proximity of the composter, "the composter is always at hand", thus the convenience of biowaste removal from home (kitchen). Only half of the respondents perceived the reduction in GHG emissions that accompany the traditional method of biowaste management (transport to a composting plant) as a significant benefit of home composting. This suggests that the respondents perceive the usefulness of home composting mainly through the prism of individual benefits. Hence, it is important that the support programs are constructed in such a way that achieving individual benefits serve the realization of general and social goals.

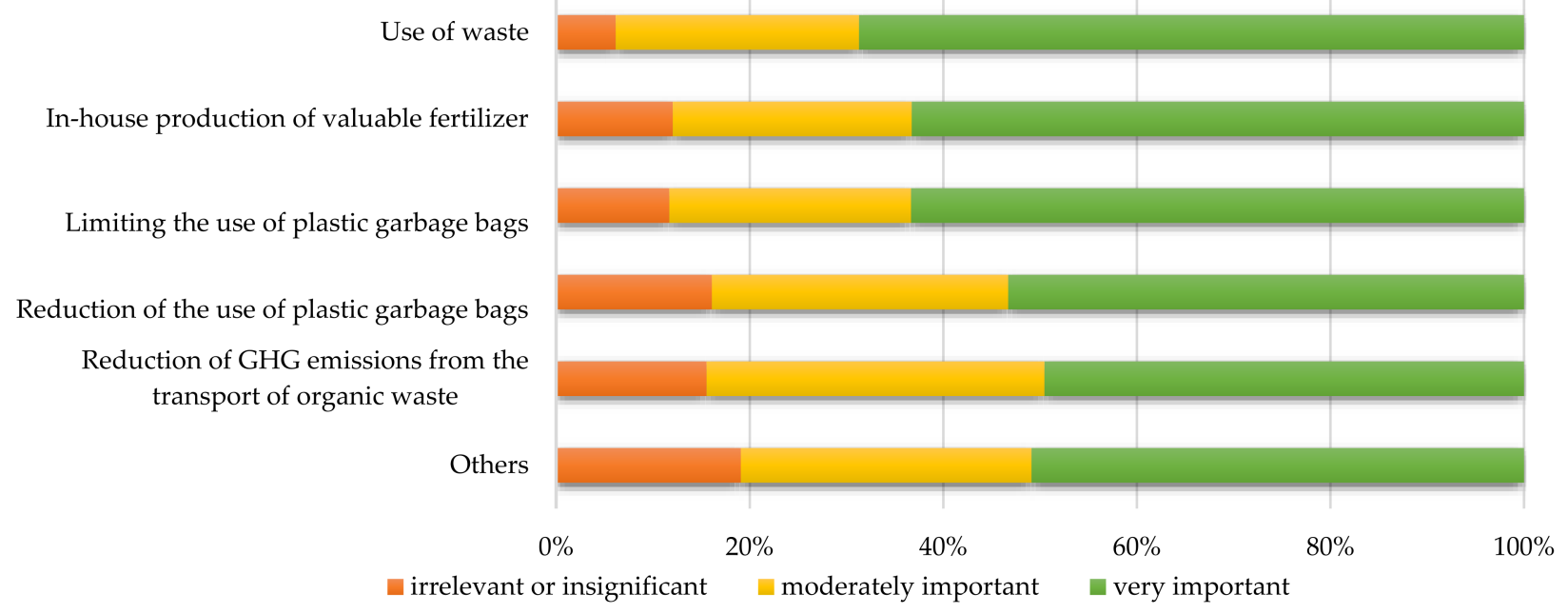

Figure 9. Assessment of the basic benefits of home composting by the surveyed respondents. Source: own study base on the survey.

The results of the analyses presented above indicate that the investment consisting in equipping the inhabitants with composters may be profitable, although the level of financial incentives (fee deduction) will be of crucial importance. The answers given by the respondents show that with a rationally justified level of fee deduction, only some households would decide to participate in the program, which would significantly differentiate the overall operating costs of the entire waste management system in the commune. Figure 10 presents a simulation of the level of costs of biowaste management depending on the degree of participation of households in the home-composting system. The involvement of $100 \%$ of eligible households (according to the adopted assumptions, it was 6928 households) would result in savings of nearly PLN 3.5 million (EUR $0.78 \mathrm{mln}$ ) (it should be borne in mind that some of the smallest facilities were excluded from the analysis; hence, a certain level of costs related to the management of biowaste is incurred by the commune independently of the scale of participation). 


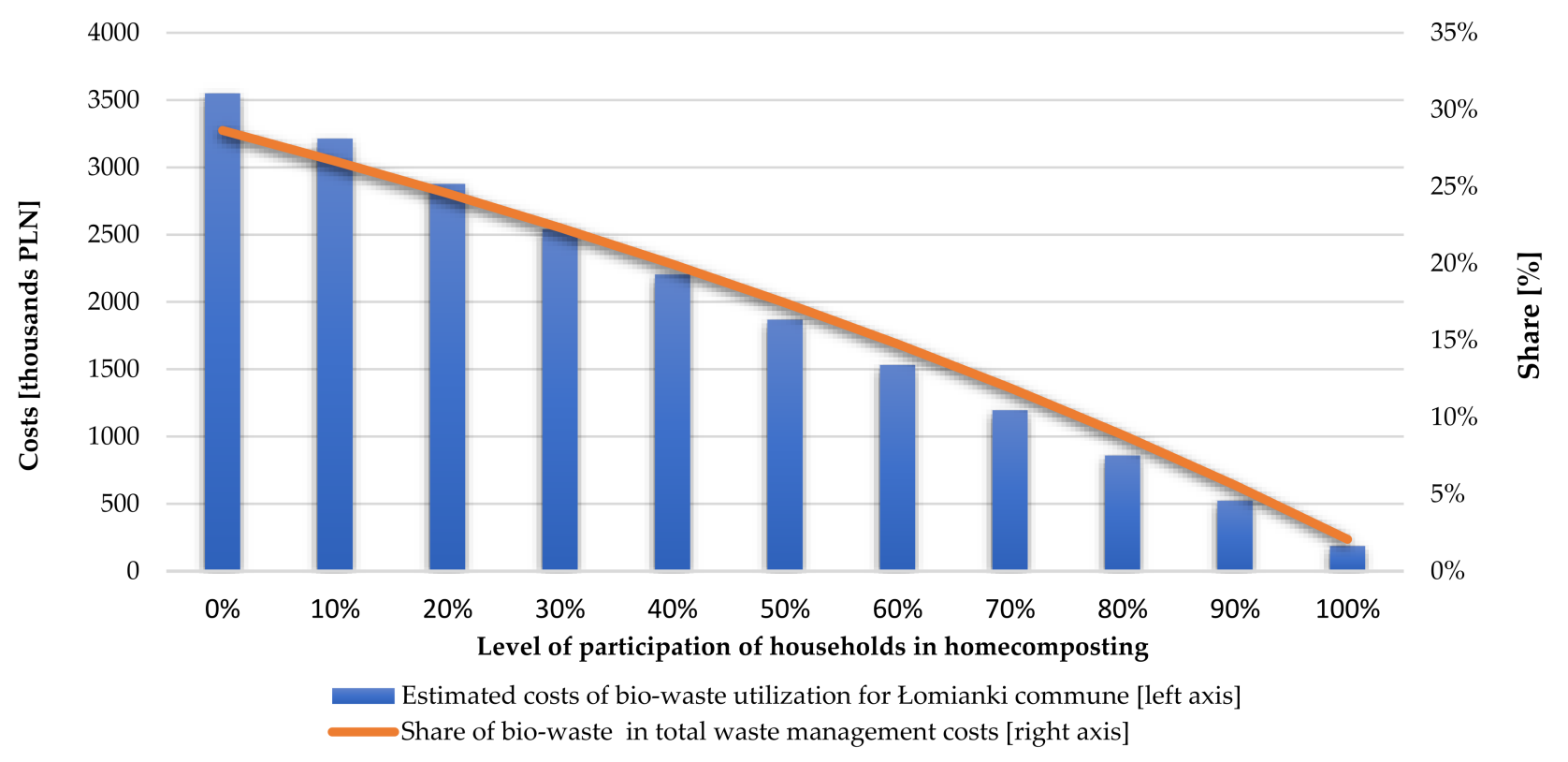

Figure 10. Changes in the level of biowaste management costs at the commune level depending on the degree of participation of households in the home-composting system. Source: own study.

When assessing the economic viability of promoting home composting, one should also consider the fact that the elimination (significant limitation) of bio-based harvesting by the commune will reduce the costs but also the value of the fees collected from residents. As indicated earlier, the level of reductions in fees for switching to home composting offered thus far is disproportionately low in relation to the benefits that the commune receives when the average household stops supplying waste to the commune collection system. This means that increasing the level of discounts may lead to a deterioration of the financial results of the entire system. Hypothetical changes in the annual financial results are understood as the difference between the contributions paid at the commune level and the costs of biowaste management-otherwise, they can be seen as the amounts necessary to cover other system costs; these changes for the entire waste management system with different levels of deduction in the fee paid by residents and different levels of participation are shown in Figure 11.

The discussed results are relative, and the figures provided refer to the initial variant, which means zero level of participation and zero levels of discounts (the number of contributions currently collected). Figure 11 shows that with the increase in the scale of participation, the financial result improves, although the dynamics of its growth slightly decrease with the increase in the percentage of participants. In the best-case scenario, from the commune's management point of view, i.e., with zero fee deduction, the inclusion of $100 \%$ of eligible households in the system would increase the pool of funds available in the system by $80 \%$. If the current level of discounts $(6 \%)$ were maintained, full participation would give annual savings of $70 \%$. Applying the $30 \%$ deduction would improve the financial result of the system from 3\% (with 10\% participation) to $29 \%$ (with $100 \%$ participation of eligible households). At higher levels of deduction (50 and 75\%), the higher the level of participation is, the greater the deterioration of the financial result is. The simulation shows that there is only limited economic justification in increasing the participation rate through financial incentives. 


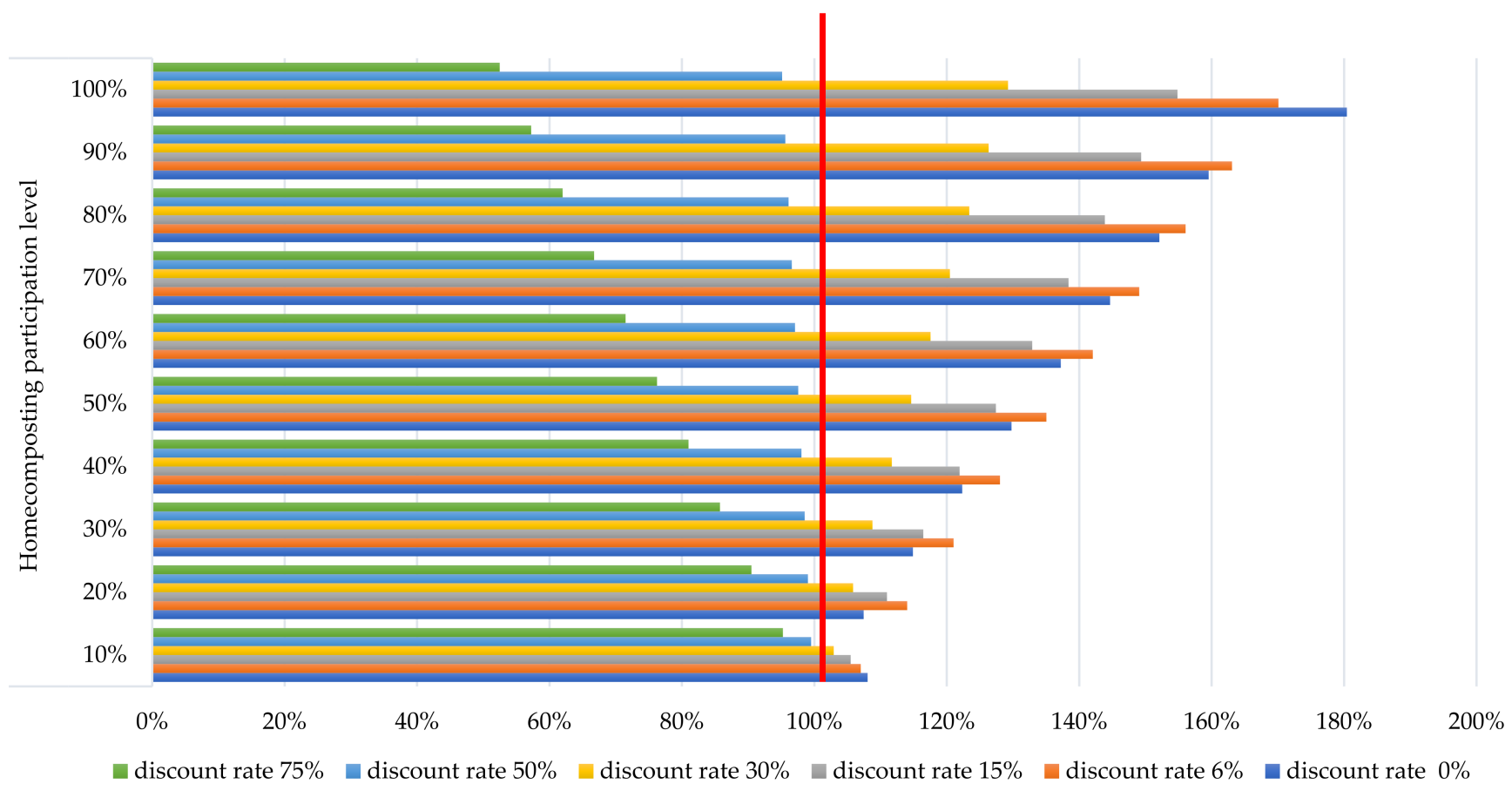

Figure 11. Changes in the financial performance of the municipal waste collection system depending on the level of participation and deduction in the biowaste fee. Source: own study.

\section{Discussion}

Striving to popularize sustainable development requires the dissemination of solutions for implementing the circular economy $[23,24,27,35]$. One of the possible ways is a change in the methods of municipal waste management, including, in particular, the dissemination of composting biodegradable waste, among which is home composting [13,14,19,62,103,104]. Despite the relatively easy technology of producing compost in the household, the popularity of home composting can be assessed as relatively low, although it varies between different countries $[14,18,61]$. In the case of Poland, there are no data illustrating the scale of the use of home composting; however, the rapidly growing costs of waste management in recent years [17] cause local authorities responsible for municipal waste management to seek alternative methods of bio-based management. Still, the scale of solutions supporting the circular economy in Polish municipal waste management remains small, although some small achievements can be highlighted [42]. One such case was analyzed in the presented research, which studied the situation in which local authorities equip households (with gardens) with composters and offer a reduction in the contribution to the waste collection system. The authors are not aware of any analysis that would assess the economic viability of such solutions, although the literature often emphasizes the economic and environmental benefits of home composting [14,49,51-53,60,62-66]. Our analyses confirm the hypothesis that home composting could be a way for municipalities (local communities) to reduce the total costs of waste management and, at the same time, indicate that this solution is part of the dissemination of the circular economy.

The results of research in Łomianki indicate the high economic profitability of the solution, although an important factor determining such a finding is the amount of discount in the contribution paid by residents to the municipal waste management system. Generally, the results obtained by us confirm the view cited in the literature on the economic and environmental legitimacy of home composting [19,60,62-64], which results from eliminating the need to transport biowaste. Our simulations show that, depending on the level of discount in fee for residents, the investment consisting in equipping households with composters by local authorities would pay off within a few years, and the maximum level of premium relief should not exceed the limit of about $40 \%$. A higher level of the 
deduction would mean that the project would not be profitable from the point of view of the commune as an investor, as the reduction in contributions would be too large in relation to the savings achieved. The problem, however, is that a significant proportion of residents expect a higher level of financial incentives. Therefore, it is reasonable to strengthen the activities aimed at making the residents aware of the benefits of home composting and to activate non-financial motivation, especially since the conducted survey shows that the reluctance to use home composting among some residents' results, among others, from lack of knowledge. Therefore, the popularization of home composting requires consistent activities in the economic dimension and in the dimension of raising the awareness of residents, which is an observation underlined in other studies [63,105].

Examples of various local composting schemes successfully implemented many years ago (in different regions of EU countries such as Spain, France, Ireland, Italy, Portugal, and the UK) show that with the right motivation by the citizens and the involvement of local authorities, the spread of biowaste composting is possible and beneficial for local communities [106]. The solution analyzed by us, which was implemented on a pilot scale in the examined commune, is therefore not completely original. However, most of the solutions implemented in the past were based mainly on a separate collection combined with locally centralized composting [106]. The approach described by us is based on the involvement of the citizens, which could be its weakness. Our survey of residents' opinions shows that some of them do not consider positive aspects of home composting, which leads to the conclusion that there is a need to increase their motivation. Other authors also mentioned this problem. For example, the analyses by Loan et al. [63] show that the key factors determining participation in the home composting program include the knowledge and attitude of residents toward this practice. Lalitha and Fernando also pointed to the importance of knowledge and awareness in popularizing home composting [105]. At the same time, the aforementioned studies indicate the correctness of our assumption that only households with gardens are included in the analyses, as it shows that this fact is crucial for the involvement of residents in home composting.

It should also be emphasized the environmental benefits of home composting, which are direct consequences of savings in energy consumption, result from the elimination of transport to a composting plant. Our analyses show that the reduction in $\mathrm{CO}_{2}$ emissions in the studied commune would amount to 41.5 thousand tons of $\mathrm{CO}_{2}$. Therefore, regardless of certain hazards related to the emission of GHG (or other substances) during the process of microbial degradation of the waste [13], one should bear in mind the direct benefits related to energy savings (reduction in transportation), as indicated by many researchers $[19,60,62-64]$. Our analyses indicate that the dissemination of home composting may be a valuable alternative to centralized systems, which was also pointed out in the studies of other authors $[62,107,108]$.

\section{Policy Implication}

The analyses carried out by us on the example of a selected commune indicate the need and the possibility of making changes to the current model of biodegradable waste management in Polish communes. However, popularizing home composting requires active support from the local authorities, which has already been postulated in other countries [109]. Such support should have both a financial dimension and a non-financial dimension related to increasing the environmental awareness of the inhabitants.

It is recommended that the assumptions of the "Composter for Everyone" program include that the number and capacity of composters handed over to the household should be strictly dependent on its needs. The main factors influencing the amount of biodegradable waste generated in a household are the number of household members and the plot area. Failure to do so can lead to problems with insufficient efficiency of the composting process in relation to the amount of waste generated (insufficient capacity or number of composters) or to unnecessarily taking up space with a too large composter. 
The aforementioned problems may be the cause of the reluctance of the inhabitants and, consequently, the reduction in the effectiveness of the program. In the long run, the investment consisting in equipping the inhabitants with composters will be profitable both for the entire commune (reducing the burden on the waste management system) and for individual residents of the commune (lower waste fees and obtaining additional fertilizers). It would also make the local community more sensitive to environmental problems.

\section{Conclusions}

Our research was based on the case study of Poland and showed that home composting can be an effective way to reduce the costs of the public waste collection system. The analyses showed that the currently offered discounts in fees for waste collection $(6 \%)$ for home composting of biowaste are too low to encourage participation in the homecomposting system. The survey shows that over $80 \%$ of respondents expect a reduction higher than $15 \%$ of the fee, including over $40 \%$ of respondents that would expect a relief above $30 \%$ of the fee. Our estimates, including the net preset value calculation, show that applying a collecting fee discount of about $30 \%$ and covering costs of equipping residents with composters at the same time would still be profitable from the point of view of the commune's budget-reduction in collected revenues from fees would be smaller than the reduction in waste management costs. This confirms the hypothesis that the dissemination of home composting is beneficial for the commune for financial reasons. The levels of reductions in fees for waste collection (resulting from national regulations) proposed by the commune thus far can therefore be considered not entirely fair (the benefits of the commune are greater than the level of concessions for participants-the level of discounts at which the NPV approaches the level of zero is about 30\%). On the other hand, people who undertake composting gain additional benefits from the fertilizers they normally would potentially buy. However, taking into account the expectations of a much higher level of fee reduction by some respondents, it should be assumed that it would be difficult to create a system in which all eligible persons would join the home-composting program. Such a conclusion is reinforced by the results of the survey showing that only $1 / 3$ of respondents declared their willingness to join or continue participation in home composting. This observation suggests the need to educate residents about both the economic and environmental benefits of biowaste composting. The dissemination of home composting allows the limitation of, among others, GHG emissions, which was one of the benefits that relatively few respondents were convinced of. Increasing the awareness of citizens in this regard is particularly important in promoting the pursuit of the circular economy model, which is one of the ways to reduce the consumption of environmental resources and activities consistent with the idea of sustainable development. Home composting, by enabling a partially closed circulation of resources within the household, is one of the simplest forms of fulfilling the assumptions of circular economy, as waste is converted into fertilizer, which might be used in home gardens. Although the chosen commune is certainly not representative of the whole society, the results show significant potential in the concept of home composting. The study reveals the need for further research toward developing an optimal model of biowaste management tailored to the needs of local communities.

Although the above-formulated conclusions lead to a generally positive assessment of the tested system from the economic and environmental point of view, it is necessary to pay attention to certain risk factors that may be particularly important when extending this solution to the entire country. It can be assumed that the popularization of the program on a national scale would increase the demand for composters and would significantly exceed the current supply. This would make it impossible to implement the program in some municipalities and probably would increase the prices of composters, reducing the economic benefits of home composting. A certain risk is also associated with environmental effects. Although self-composting leads to a reduction in GHG emissions due to the elimination of transport, technological errors in the composting process may result in unnecessary substances entering the natural environment. However, due to the small 
scale of the activity, this threat seems to be not significant. A more serious risk seems to appear in the social sphere and is related to the inhabitants' attitudes. Some of them may be characterized by a "moral hazard," i.e., that biodegradable waste should be placed in the bin devoted to the "mixed" category of wastes. Thus, in fact, they would remain in the system of collecting biowaste despite paying a lower premium. Therefore, it seems reasonable to conduct extensive educational activities in addition to implementing an appropriate control system.

Author Contributions: Conceptualization, A.W. and P.S.; methodology, P.S., K.K. and G.R.; software, K.K.; validation, P.S. and A.W.; formal analysis, P.S., G.R., K.K. and K.U.; investigation, G.R., K.U. and K.K.; data curation, G.R., K.K. and K.U.; writing-original draft preparation, P.S. and M.G.; writing-review and editing, A.W. and M.G.; visualization, M.G.; supervision, P.S. and A.W.; project administration, A.W. All authors have read and agreed to the published version of the manuscript.

Funding: This research received no external funding.

Institutional Review Board Statement: Not applicable.

Informed Consent Statement: Not applicable.

Acknowledgments: The authors would like to express their gratitude to the authorities of the Łomianki commune for their support during the collection of data and to the Foundation for the Promotion of Recreation "KiM" from Łomianki for inspiration and drawing attention to the importance of local activities for the quality of our life and the condition of the planet.

Conflicts of Interest: The authors declare no conflict of interest.

\section{References}

1. OECD. Beyond Growth: Toward a new economic approach. In Report of the Secretary General's Advisory Group on a New Growth Narrative; OECD: Paris, France, 2019.

2. Ellen MacArthur Foundation. Towards the circular economy. In Economic and Business Rationale for an Accelerated Transition; Ellen MacArthur Foundation: Cowes, UK, 2013.

3. Savini, F. The economy that runs on waste: Accumulation in the circular city. J. Environ. Policy Plan. 2019, 21, 675-691. [CrossRef]

4. Wilson, D.C.; Rodić, L.; Modak, P.; Soos, R.; Carpintero, A.; Velis, K.; Iyer, M.; Simonett, O. Global Waste Management Outlook; UNEP: Nairobi, Kenya, 2015.

5. Kaza, S.; Yao, L.; Bhada-Tata, P.; Van Woerden, F.; Ionkova, K.; Morton, J.; Poveda, R.A.; Sarraf, M.; Malkawi, F.; Harinath, A.S.; et al. What a Waste 2.0: Global Snapshot of Solid Waste Management to 2050; World Bank Publications: Washington, DC, USA, 2018.

6. German NGO. Forum on Environment and Development Theecological Dimension in the Post-2015 Agenda for Sustainable Development; German NGO: Berlin Germany, 2013.

7. Rodić, L.; Wilson, D.C. Resolving Governance issues to achieve priority sustainable development goals related to solid waste management in developing countries. Sustainability 2017, 9, 404. [CrossRef]

8. Weitz, N.; Carlsen, H.; Skånberg, K.; Dzebo, A.; Viaud, V. SDGs and the Environment in the EU: A Systems View to Improve Coherence Report Commissioned by the European Environment Agency; Stockholm Environment Institute: Stockholm, Sweden, 2019.

9. Lemaire, A.; Limbourg, S. How can food loss and waste management achieve sustainable development goals? J. Clean. Prod. 2019, 234, 1221-1234. [CrossRef]

10. European Commission. Commission of European Communities a New Circular Economy Action Plan For a Cleaner and More Competitive Europe, Communication No. 98; European Commission: Brussels, Belgium, 2020.

11. European Commission. Commission of European Communities Towards a Circular Economy: A Zero Waste Programme for Europe, Communication No. 398; European Commission: Brussels, Belgium, 2014.

12. European Commission. Commission of European Communities Monitoring Framework for the Circular Economy, Communication No. 29; European Commission: Brussels, Belgium, 2018.

13. Andersen, J.; Boldrin, A.; Christensen, T.H.; Scheutz, C. Home composting as an alternative treatment option for organic household waste in Denmark: An environmental assessment using life cycle assessment-modelling. Waste Manag. 2012, 32, 31-40. [CrossRef]

14. EEA. Bio-Waste in Europe-Turning Challenges into Opportunities. Report No 4/2020; EEA: Copenhagen, Denmark, 2020.

15. Colón, J.; Martínez-Blanco, J.; Gabarrell, X.; Artola, A.; Sánchez, A.; Rieradevall, J.; Font, X. Environmental assessment of home composting. Resources, Conservation and Recycling 2010, 54, 893-904. [CrossRef]

16. Central Statistical Office. Odpady Komunalne i Odpady Zbierane Selektywnie w Ciagu Roku (eng. Municipal Waste and Waste Collected Selectively During the Year); Central Statistical Office: Warsaw, Poland, 2020. 
17. The National Chamber of Statutory Auditors. Sprawozdanie z Działalności Regionalnych izb Obrachunkowych i Wykonania Budżetu Przez Jednostki Samorzadu Terytorialnego w 2020 Roku (eng. Report on the Activities of Regional Accounting Chambers and Budget Implementation by Local Government Units in 2020 National Council of the Regional Chambers of Audit; The National Chamber of Statutory Auditors: Warsaw, Poland, 2021.

18. Seyring, N.; Dollhofer, M.; Weißenbacher, J.; Márton, M.; Herczeg, M.; Bakas, I.; Mckinnon, D. Assessment of Separate Collection Schemes in the 28 Capitals of the EU; Publications Office of the European Union: Luxembourg, 2015.

19. Vázquez, M.A.; Plana, R.; Pérez, C.; Soto, M. Development of technologies for local composting of food waste from universities. Int. J. Environ. Res. Public Health 2020, 17, 3153. [CrossRef]

20. Boulding, K.E. The economics of the coming spaceship earth. In Environmental Quality in a Growing Economy; Henry, J., Ed.; The Johns Hopkins Press: Baltimore, MD, USA, 1966.

21. Gołębiewski, J. Systemy Żywnościowe w Warunkach Gospodarki Cyrkularnej Studium Porównawcze Krajów Unii Europejskiej (eng. Food Systems in the Conditions of Circular Economy. Comparative Study of European Union Countries); Wydawnictwo SGGW: Warszawa, Poland, 2019; ISBN 9788375838329.

22. Saavedra, Y.M.; Iritani, D.R.; Pavan, A.L.R.; Ometto, A.R. Theoretical contribution of industrial ecology to circular economy. J. Clean. Prod. 2018, 170, 1514-1522. [CrossRef]

23. Corona, B.; Shen, L.; Reike, D.; Carreón, J.R.; Worrell, E. Towards sustainable development through the circular economy-A review and critical assessment on current circularity metrics. Resour. Conserv. Recycl. 2019, 151, 104498. [CrossRef]

24. Berg, A.; Antikainen, R.; Hartikainen, E.; Kauppi, S.; Kautto, P.; Lazarevic, D.; Piesik, S.; Saikku, L. Circular Economy for Sustainable Development; Finnish Environment Institute: Helsinki, Finland, 2018.

25. Cabot, M.I.; Luque, A.; Heras, A.D.L.; Aguayo, F. Aspects of sustainability and design engineering for the production of interconnected smart food packaging. PLoS ONE 2019, 14, e216555. [CrossRef]

26. McDonough, W.; Braungart, M. Cradle to Cradle: Remaking the Way We Make Things; North Point Press A division of Farrar, Straus and Giroux: New York, NY, USA, 2002.

27. Toxopeus, M.E.; De Koeijer, B.; Meij, A. Cradle to Cradle: Effective Vision vs. Efficient Practice? Procedia CIRP 2015, 29, 384-389. [CrossRef]

28. Jørgensen, S.; Pedersen, L.J.T. The circular rather than the linear economy. In Restart Sustainable Business Model Innovation; Shriwastava, P., Zsolnai, L., Eds.; Springer International Publishing: New York, NY, USA, 2018; pp. $103-120$.

29. Braungart, M.; McDonough, W.; Bollinger, A. Cradle-to-cradle design: Creating healthy emissions-A strategy for eco-effective product and system design. J. Clean. Prod. 2007, 15, 1337-1348. [CrossRef]

30. Scheel, C.; Aguiñaga, E.; Bello, B. Decoupling economic development from the consumption of finite resources using circular economy. A model for developing countries. Sustainability 2020, 12, 1291. [CrossRef]

31. United Nations Environmental Programme. Decoupling Natural Resource Use and Environmental Impacts from Economic Growth; International Resource Panel: Paris, France, 2011.

32. Giampietro, M. On the Circular Bioeconomy and Decoupling: Implications for Sustainable Growth. Ecol. Econ. 2019, 162, 143-156. [CrossRef]

33. Calvo-Porral, C.; Lévy-Mangin, J.-P. The circular economy business model: Examining consumers' acceptance of recycled goods. Adm. Sci. 2020, 10, 28. [CrossRef]

34. Sijtsema, S.J.; Snoek, H.M.; Van Haaster-de Winter, M.A.; Dagevos, H. Let's Talk about circular economy: A qualitative exploration of consumer perceptions. Sustainability 2019, 12, 286. [CrossRef]

35. European Commission. Closing the Loop-An EU Action Plan for the Circular Economy. Communication No. 614; European Commission: Brussels, Belgium, 2015.

36. Camacho-Otero, J.; Boks, C.; Pettersen, I.N. Consumption in the Circular Economy: A Literature Review. Sustainability 2018, 10, 2758. [CrossRef]

37. Norwegian Ministry of the Environment. Report of the Symposium on Sustainable Consumption; Norwegian Ministry of the Environment: Oslo, Norway, 1994.

38. OECD. Education and Learning for Sustainable Consumption COM/ENV/CERI (99)64; OECD: Paris, France, 1999.

39. Bengtsson, M.; Alfredsson, E.; Cohen, M.; Lorek, S.; Schroeder, P. Transforming systems of consumption and production for achieving the sustainable development goals: Moving beyond efficiency. Sustain. Sci. 2018, 13, 1533-1547. [CrossRef]

40. OECD. OECD 2008: Promoting Sustainable Consumption. Good Practices in OECD Countries 40; OECD: Paris, France, 2008.

41. Ekström, K.M. waste management and sustainable consumption. In Reflections On Consumer Waste; Routledge: London, UK; New York, NY, USA, 2014.

42. Smol, M.; Duda, J.; Czaplicka-Kotas, A.; Szołdrowska, D. Transformation towards Circular Economy (CE) in municipal waste management system: Model solutions for Poland. Sustainability 2020, 12, 4561. [CrossRef]

43. Lehmann, S. Optimizing urban material flows and waste streams in urban development through principles of zero waste and sustainable consumption. Sustainability 2011, 3, 155-183. [CrossRef]

44. Hamid, S.; Skinder, B.M.; Bhat, M.A. Zero waste: A sustainable approach for waste management. In Innovative Waste Management Technologies for Sustainable Development; Bhat, R.A., Quadri, H., Wani, K., Dar, G.H., Mehmood, M.A., Eds.; IGI Global Publisher of Timely Knowledge: Hershey, PA, USA, 2020; pp. 134-155. Available online: https://www.igi-global.com/gateway/chapter/23 4624 (accessed on 11 June 2021). 
45. Bolton, K.; Rousta, K. Solid waste management toward zero landfill: A Swedish model. In Sustainable Resource Recovery and Zero Waste Approaches; Elsevier: Amsterdam, The Netherlands, 2019.

46. Mesjasz-Lech, A. Municipal waste management in context of sustainable urban development. Procedia Soc. Behav. Sci. 2014, 151, 244-256. [CrossRef]

47. Wąs, A.; Sulewski, P.; Szymańska, M. Biorafinerie Rolnicze Jako Element Trwałej Gospodarki (eng. Agricultural Biorefineries as an Element of Sustainable Economy); Wydawnictwo SGGW: Warsaw, Poland, 2019.

48. Pilarska, A.; Pilarski, K. Parametry procesu kompostowania (eng. Composting process parameters). Tech. Rol. Ogrod. Leśna 2009, $1,16-22$.

49. Ayilara, M.S.; Olanrewaju, O.S.; Babalola, O.O.; Odeyemi, O. Waste Management through composting: Challenges and potentials. Sustainability 2020, 12, 4456. [CrossRef]

50. Golueke, C. Bacteriology of composting. Biocycle 1992, 33, 55-57.

51. Adugna, G. A Review on impact of compost on soil properties, water use and crop productivity. Acad. Res. J. Agric. Sci. Res. 2016, 4, 93-104. [CrossRef]

52. Tejada, M.; Hernandez, T.; Garcia, C. Soil restoration using composted plant residues: Effects on soil properties. Soil Tillage Res. 2009, 102, 109-117. [CrossRef]

53. Ros, M. Soil microbial activity after restoration of a semiarid soil by organic amendments. Soil Biol. Biochem. 2003, 35, 463-469. [CrossRef]

54. Debertoldi, M.; Vallini, G.; Pera, A. The biology of composting: A review. Waste Manag. Res. 1983, 1, 157-176. [CrossRef]

55. Hassen, A.; Belguith, K.; Jedidi, N.; Cherif, A.; Cherif, M.; Boudabous, A. Microbial characterization during composting of municipal solid waste. Bioresour. Technol. 2001, 80, 217-225. [CrossRef]

56. Massiani, C.; Domeizel, M. Quality of composts: Organic matter stabilization and trace metal contamination. In The Science of Composting; De Bertoldi, M., Sequi, P., Lemmes, B., Papi, T., Eds.; Springer: Heidelberg, The Netherlands, 1996 ; pp. 185-194.

57. Al-Rumaihi, A.; McKay, G.; Mackey, H.R.; Al-Ansari, T. Environmental impact assessment of food waste management using two composting techniques. Sustainability 2020, 12, 1595. [CrossRef]

58. Lou, X.; Nair, J. The impact of landfilling and composting on greenhouse gas emissions-A review. Bioresour. Technol. 2009, 100, 3792-3798. [CrossRef]

59. Friedrich, E.; Trois, C. Quantification of greenhouse gas emissions from waste management processes for municipalities-A comparative review focusing on Africa. Waste Manag. 2011, 31, 1585-1596. [CrossRef]

60. Adhikari, B.K.; Trémier, A.; Barrington, S.; Martinez, J.; Daumoin, M. Gas emissions as influenced by home composting system configuration. J. Environ. Manag. 2013, 116, 163-171. [CrossRef]

61. European Bioplastics. Fact Sheet APR Home Composting; European Bioplastics: Berlin, Germany, 2015.

62. Bruni, C.; Akyol, C.; Cipolletta, G.; Eusebi, A.L.; Caniani, D.; Masi, S.; Colón, J.; Fatone, F. Decentralized community composting: Past, present and future aspects of Italy. Sustainability 2020, 12, 3319. [CrossRef]

63. Loan, L.T.T.; Takahashi, Y.; Nomura, H.; Yabe, M. Modeling home composting behavior toward sustainable municipal organic waste management at the source in developing countries. Resour. Conserv. Recycl. 2018, 140, 65-71. [CrossRef]

64. Tatàno, F.; Pagliaro, G.; Di Giovanni, P.; Floriani, E.; Mangani, F. Biowaste home composting: Experimental process monitoring and quality control. Waste Manag. 2015, 38, 72-85. [CrossRef]

65. Mesaric, J.; Franjkovic, J.; Šebalj, D. Supply chains in the context of life cycle assessment and sustainability. In Proceedings of the 16th International Scientific Conference Business Logistics in Modern Management, Osijek, Croatia, 13 October 2016.

66. Vázquez, M.; Soto, M. The efficiency of home composting programmes and compost quality. Waste Manag. 2017, 64, 39-50. [CrossRef]

67. Eurostat Municipal waste by waste management operations. Available online: https://ec.europa.eu/eurostat/databrowser/ view / env_wasmun/default/bar?lang=en (accessed on 28 June 2021).

68. Zaleski, P.; Chawla, Y. Circular economy in Poland: Profitability analysis for two methods of waste processing in small municipalities. Energies 2020, 13, 5166. [CrossRef]

69. WFD 2008/98/EC: Directive 2008/98/EC on waste (Waste Framework Directive). Available online: https:/ / eur-lex.europa.eu/ legal-content/EN/TXT/?uri=celex\%3A32008L0098 (accessed on 25 June 2021).

70. European Commission Directive (EU). 2018/851 of the European Parliament and of the Council of 30 May 2018 Amending Directive 2008/98/EC on Waste; European Commission Directive: Brussels, Belgium, 2018.

71. Eurostat. Available online: Ec.europa.eu/eurostat/data/database (accessed on 18 June 2021).

72. Council of Ministers Mapa Drogowa. Transformacja w Kierunku Gospodarki o Obiegu Zamkniętym (eng. Roadmap. Transformation Towards a Circular Economy); Council of Ministers Mapa Drogowa: Warsaw, Poland, 2019.

73. Alwaeli, M. An overview of municipal solid waste management in Poland. The current situation, problems and challenges. Environ. Prot. Eng. 2015, 41. [CrossRef]

74. Perepeczko, B. Świadomość ekologiczna mieszkańców i ich postawy proekologiczne (eng. Ecological awareness of the inhabitants and their pro-ecological attitudes). In Uwarunkowania Zrównoważonego Rozwoju Gmin Objętych Siecią Natura 2000 w Świetle Badań Empirycznych (eng. Conditions for the Sustainable Development of Municipalities Included in the Natura 2000 Network in the Light of Empirical Research); Bałtromiuk, A., Ed.; IRWiR PAN: Warsaw, Poland, 2011; pp. 187-212. 
75. Korzeniowska-Ginter, R.; Dereszewska, A.; Spigarska, E. Consumer attitude towards the implementation of the idea of bakery and confectionery waste segregation ",at sources". Rocz. Nauk. Ser. 2016, XVIII, 184-190.

76. Kostecka, J.; Dunin-Mugler, C. Partycypacja społeczna a segregacja odpadów organicznych (eng. Social participation and organic waste segregation). Inżynieria Ekol. 2011, 27, 81-91.

77. Jakubus, M.; Tatuśko, N. Separate collection of municipal waste in knowledge and social participation aspects. Inżynieria Ekologiczna 2015, 41, 108-116. [CrossRef]

78. Perks, M. Composting program participation and availability across canada. Sojourners Undergrad. J. Sociol. 2015, 6, 42-57.

79. Kala, K.; Bolia, N.B. Analysis of citizen's perception towards segregation and composting. Environ. Dev. Sustain. 2020, 23, 10763-10786. [CrossRef]

80. Marcello, B.; Di Gennaro, V.; Ferrini, S. Let the citizens speak: An empirical economic analysis of domestic organic waste for community composting in Tuscany. J. Clean. Prod. 2021, 306, 127263. [CrossRef]

81. Bashir, M.J.K.; Tao, G.H.; Abu Amr, S.S.; Tan, K.W. Public concerns and behaviors towards solid waste minimization using composting in Kampar district, Malaysia. Glob. Nest J. 2018, 20, 316-323.

82. Tucker, P.; Speirs, D.; Fletcher, S.I.; Edgerton, E.; McKechnie, J. Factors affecting take-up of and drop-out from home composting schemes. Local Environ. 2003, 8, 245-259. [CrossRef]

83. Łomianki Municipal Office. Pod Lupa. Rewolucja w Gospodarce Odpadami Komunalnymi (eng. Under the Magnifying Glass. Revolution in Municipal Waste Management). Available online: https://lomianki.pl/ftp/biuletyn/BIUM_1_2020_donetu_1.pdf (accessed on 25 June 2021).

84. Poland in numbers Commune of Łomianki in numbers. Available online: https://www.polskawliczbach.pl/gmina_Lomianki\# dane-demograficzne (accessed on 2 July 2021).

85. Łomianki Municipal Office. Uchwała Nr XX/179/2020. Available online: https://bip.lomianki.pl/bip/prawo-lokalne/uchwalyrady-miejskiej/2020/10006,Uchwala-Nr-XX1792020-z-dnia-30-stycznia-2020-roku-w-sprawie-miejscowego-planu-za.html (accessed on 15 June 2021).

86. Dabrowski, T. Łomianki Commune Website. Available online: https://www.lomianki.pl/pl/aktualnosci/2540,Kompostownikdla-kazdego.html (accessed on 28 June 2021).

87. NGO. Natural and Ecological Education. Available online: https://www.fundacjakim.pl/dzialania-fundacji/edukacjaprzyrodniczo-ekologiczna.html (accessed on 9 August 2021).

88. Łomianki Municipal Office. Analiza Stanu Gospodarki Odpadami Komunalnymi Gminy Łomianki w 2019 Roku (eng. Analysis of the State of the Municipal Economy in the Łomianki Commune in 2019). Available online: https://bip.lomianki.pl/download/ 2/25896/ Analizastanugospodarkiodpadamikomunalnymi2019.pdf (accessed on 12 July 2021).

89. Act on the Maintenance of Cleanliness and Order in Communes, 1966. In Journal of Laws of the Republic of Poland of 2019, position 2010 i 2020. Available online: https:/ / dziennikustaw.gov.pl/D2019000201001.pdf (accessed on 28 June 2021).

90. 29th December 2016 on the Detailed Method of Selective Collection of Selected Fractions Regulation of the Minister of the Environment. In Journal of Laws of the Republic of Poland; 2019. Available online: https:/ /isap.sejm.gov.pl/isap.nsf/download.xsp/ WDU20170000019/O/D20170019.pdf (accessed on 29 June 2021).

91. Kostecka, J.; Pączka, G.; Garczyńska, M.; Podolak-Machowska, A.; Dunin-Mugler, C.; Szura, R. Wykorzystanie wermikompostowania do zagospodarowania odpadów organicznych w gospodarstwach domowych (eng. The use of vermicomposting for the management of organic waste in households). Inżynieria i Ochr. Środowiska 2014, 17, 21-30.

92. Szpadt, R. Problemy gospodarki odpadami komunalnymi ulegajacymi biodegradacji (eng. Problems of municipal biodegradable waste management). Available online: http:/ / www.pzits-cedeko.com.pl/referaty/Ryszard_Szpadt.pdf (accessed on 16 June 2021).

93. Zamorowska, K. Mikroorganizmy odpowiedzią na problemy z zagospodarowaniem bioodpadów (eng. Microorganisms as a response to problems with bio-waste management). Available online: https:/ /www.teraz-srodowisko.pl/aktualnosci/ mikroorganizmy-odpowiedzia-na-problemy-z-zagospodarowaniem-bioodpadow-6509.html (accessed on 6 June 2021).

94. Wysocki, C.; Stawicka, J. Trawy na terenach zurbanizowanych (eng. Grasses in urban aeras). In Grassland Science in Poland; Goliński, P., Kozłowski, S., Golińska, B., Eds.; Polskie Towarzystwo Łąkarskie: Poznań, Poland, 2005; p. 232.

95. Mbuligwe, S.; Kassenga, G.; Kaseva, M.; Chaggu, E. Potential and constraints of composting domestic solid waste in developing countries: Findings from a pilot study in Dar es Salaam, Tanzania. Resour. Conserv. Recycl. 2002, 36, 45-59. [CrossRef]

96. Breitenbeck, G.A.; Schellinger, D. Calculating the reduction in material mass and volume during composting. Compos. Sci. Util. 2004, 12, 365-371. [CrossRef]

97. Wong, J.W. Effects of lime addition on sewage sludge composting process. Water Res. 2000, 34, 3691-3698. [CrossRef]

98. Chen, L.; de Haro Marti, M.; Moore, A.; Falen, C. The Composting Process. Available online: https://www.extension.uidaho. edu/publishing/pdf/CIS/CIS1179.pdf (accessed on 28 June 2021).

99. Elango, D.; Thinakaran, N.; Panneerselvam, P.; Sivanesan, S. Thermophilic composting of municipal solid waste. Appl. Energy 2009, 86, 663-668. [CrossRef]

100. Erler, E. Can you compost in winter? University of New Hampshire. Available online: https://extension.unh.edu/blog/2020/11/ can-you-compost-winter (accessed on 9 September 2021).

101. Mazik, M. How to speed up the composting? Available online: https://zielonyogrodek.pl/pielegnacja/nawozenie/5416-jakprzyspieszyc-kompostowanie (accessed on 14 June 2021). 
102. Witaszek, M.; Witaszek, K. Comparison of carbon dioxide emission for different modes of transport. Sci. J. Silesian Univ. Technol. Ser. Transp. 2015, 88, 145-153. [CrossRef]

103. Francesco, R.; Lorenzo, D.; Giovanni, L.; Lazzeri, L. The role of compost in bio-waste management and circular economy. In Designing Sustainable Technologies, Products and Policies. From Science to Innovation; Benetto, E., Gericke, K., Guiton, M., Eds.; Springer Open: Luxembourg, 2017; pp. 133-143.

104. Adami, L.; Schiavon, M. From circular economy to circular ecology: A Review on the Solution of environmental problems through circular waste management approaches. Sustainability 2021, 13, 925. [CrossRef]

105. Fernando, R.L.S. People's participation in home composting: An exploratory study based on Moratuwa and Kaduwela municipalities in the Western Province of Sri Lanka. Manag. Environ. Qual. Int. J. 2020, 32, 344-358. [CrossRef]

106. European Commission. Success Stories on Composting and Separate Collection; European Commission: Brussels, Belgium, 2000; Available online: https:/ / op.europa.eu/en/publication-detail/-/publication/dc960474-5b04-4b95-80cf-6ef658e08ab4 (accessed on 18 June 2021).

107. De Kraker, J.; Kujawa-Roeleveld, K.; Villena, M.J.; Pabón-Pereira, C. Decentralized valorization of residual flows as an alternative to the traditional urban waste management system: The Case of Peñalolén in Santiago de Chile. Sustainability 2019, 11, 6206. [CrossRef]

108. Sakarika, M.; Spiller, M.; Baetens, R.; Donies, G.; Vanderstuyf, J.; Vinck, K.; Vrancken, K.C.; Van Barel, G.; Du Bois, E.; Vlaeminck, S.E. Proof of concept of high-rate decentralized pre-composting of kitchen waste: Optimizing design and operationof a novel drum reactor. Waste Manag. 2019, 91, 20-32. [CrossRef]

109. Mitaftsi, O. Quantifying Household Waste Diversion from Landfill Disposal by Home Composting and Kerbside Collection; Department of Civil and Environmental engineering, Imperial College London: London, UK, 2008. 